\title{
THE ROLE OF CROSS-BORDER MERGERS AND ACQUISITIONS IN ASIAN RESTRUCTURING
}

\author{
Ashoka Mody and Shoko Negishi ${ }^{1}$
}

August 3, 2000

\footnotetext{
${ }^{1}$ The authors are, respectively, Lead Specialist and Economist in the Development Prospects Group, the World Bank. They are grateful to Richard Newfarmer and others at the Foreign Investment Advisory Service/Poverty Reduction and Economic Management (PREM) Network seminar series. The research was partially funded by the Growth Thematic Group of the PREM network. The views expressed here are those of the authors and not necessarily those of the World Bank.
} 


\begin{abstract}
Asset purchases by international firms in developing countries (cross-border mergers and acquisitions or M\&A), involving more than a 50 percent stake, rose sharply in value from $\$ 19$ billion in 1996 to $\$ 43$ billion and \$47 billion in 1997 and 1998, and fell slightly in 1999. The rise was fuelled in part by the purchase of distressed assets in the East Asian crisis countries (especially in Korea and Thailand). East Asian M\&A deals jumped from $\$ 2$ billion in 1996 to $\$ 7$ billion in 1997, and further up to $\$ 10$ billion in 1998. Latin America M\&A deals also increased rapidly but, in contrast to East Asia, were the result of asset acquisition by foreigners under privatization programs. The increased capital flows through M\&A deals were welcome as capital market inflows fell sharply and foreign direct investment in new projects remained stable, or even declined.
\end{abstract}

Though on the rise, cross-border M\&A in developing countries form less than 20 percent of global cross-border M\&A activity. International mega-mergers, which are integrating activities across borders to exploit technological and marketing synergies and are thus potentially transforming several major industrial sectors, are yet to have a significant influence on developing countries. Recent developing country M\&A may be characterized as a first step in the integration process. That first step entails a restructuring of production and marketing activities to bring the developing country partner in line with the best operating procedures. In principle, cross-border M\&A can facilitate corporate and financial restructuring by improving the efficiency of operations as well as by reducing excess capacity. The new management and financial resources made available through international M\&As can be especially useful following a systemic crisis that affects a large number of firms and banks, as in East Asia.

Following an overview of trends in cross-border M\&A, we focus in this paper on the recent East Asian experience. As troubled firms continue to negotiate debt rescheduling and forgiveness, either directly with their creditors or under government-led programs, severely distressed firms, particularly in the non-tradable sectors, have been compelled to seek buyers for their assets. At the same time, the Korean and Thai governments have introduced a series of policy reforms to attract foreign investment and promote domestic and cross-border mergers and acquisitions to facilitate asset reallocation. However, this study finds that cross-border mergers and acquisitions have not made an immediate contribution to restructuring of the troubled economies. The most significant role for cross-border M\&As lies in longer-term processes such as operational restructuring and reallocation of assets. After discussing several policy measures to increase the quantum of M\&A deals, the paper notes the obvious importance of concomitant enhancements in competition policy and corporate governance. 


\section{Introduction}

This paper is motivated by four principal objectives:

- To describe recent trends in cross-border mergers and acquisition (M\&A) activity in developing countries (Section 2).

- To review the literature on the role that M\&A can play in enhancing economic efficiency (Section 3).

- To provide an empirical assessment of the role played thus far by cross-border M\&A in the restructuring of corporate sector in East Asia following the recent crisis (Sections 4 and 5).

- And, finally, to draw policy lessons on mechanisms that facilitate M\&A and hence permit their efficient execution while also recognizing the need for complementary measures to enhance competition and improve corporate governance (Section 6).

Cross-border M\&A activity has been on the rise worldwide, driving the upsurge in foreign direct investment (FDI) over the past decade, and especially over the past few years. While industrialized countries account for a dominating 90 percent share of the value of world cross-border M\&As, Latin America and East Asia developing countries have, is significant and the value of cross-border M\&As in these countries is on the rise. The benefits of such M\&A activity remain controversial. By enhancing the competition for corporate control, mergers can improve efficiency. Some studies show that acquisitions can be especially useful in restructuring underperforming firms.

Before-and-after comparisons of cash flow returns of acquired firms conclude that acquisitions bring higher wealth gains for insolvent firms than those under independent work-out, and that those gains are higher in cross-border transactions than domestic 
M\&As. At the same time, mergers can also destroy value where the projected synergies do not materialize and/or the corporate cultures clash (see Ghemawat and Ghadar 2000, Economist 2000)

In this context, cross-border mergers in the East Asian crisis countries are of special interest. ${ }^{2}$ Though financial reengineering of debt owed by troubled firms, including under government-sponsored voluntary work-out schemes, has made progress, severely distressed firms, particularly in the non-tradable sectors, have been compelled to seek buyers for their assets. The Korean and Thai governments, in particular, have introduced a series of policy reforms to create a better environment for foreign investment as well as domestic and cross-border mergers and acquisitions to enhance asset reallocation.

This paper empirically examines the sectoral patterns of cross-border merger and acquisition activity and their relationship to recovery in East Asia. The main findings are:

- Cross-border M\&A activity has occurred primarily in the most distressed sectors, such as non-tradable sectors. On the other hand, the sectors that are performing relatively well have less M\&A activity.

- There is insufficient evidence to suggest so-called "fire-sales" of distressed assets.

- But, equally, we found little sign of immediate contributions of cross-border M\&As to the restructuring of the troubled economies. Our evidence is, however, tentative since we use industry averages rather than firm-level data. However, the lack of an impact is not implausible. Given the gravity of problems, especially in the non- 
tradable sectors, it is not surprising that the restructuring effects of cross-border M\&As have not yet materialized. The most significant role for cross-border M\&As, therefore, lies ahead in the longer-term processes such as operational restructuring and reallocation of assets.

- Government policies to enhance domestic mergers and acquisitions, greater competition, and improved corporate governance will reinforce the beneficial effects of foreign mergers and acquisitions.

\section{Cross-Border M\&A: Trends, Motives, and Impacts}

This section reports on cross-border M\&A trends and, in particular, compares them with trends in FDI. In doing so, however, one important caveat needs to be noted. M\&A is a form of FDI. However, the balance of payments data does not distinguish between M\&A and "greenfield" FDI (new projects). Hence the comparison has to be made on reported values of cross-border M\&As; these reported values, unfortunately, include amounts that are not components of the balance of payments reporting of FDI data. As such, the two series cannot be directly compared. The amount recorded as FDI refers to funds channeled through the capital account of a country in relation to both M\&A and new projects; these transferred amounts can either be equity, reinvested earnings, or intercompany debt (i.e., debt issued by the parent to the subsidiary company). In contrast, cross-border M\&A data refer to transaction values. If, for example, the foreign acquiring company raises debt within the domestic market to purchase the target company, that

\footnotetext{
${ }^{2}$ All the statistical references to cross-border mergers and acquisitions in this paper involve acquisitions of more than a 50 percent equity stake by foreign investors unless otherwise noted.
} 
amount is also included in the reported values. In practice, such amounts are not likely to be large. Additionally, and perhaps more importantly, the acquiring company may borrow internationally to finance the purchase of the target company. Unlike domestic debt, such international debt financing does represent a transfer of resources to the recipient country. However, the comparison with FDI flows breaks down since, as noted, those flows include only inter-company debt. In practice, it is difficult to judge how important even this difference is. For FDI also it is possible that the international firm may borrow internationally and then on-lend on its own account to its foreign subsidiary.

Cross-border M\&As have increased significantly in industrialized as well as developing countries over the past decade. Although developing countries share of crossborder M\&As is still small relative to industrialized countries, transactions in Latin America (primarily through privatization) and East Asia (post-crisis asset sales) have led an upsurge among developing countries. In East Asia, Korea and Thailand in particular have attracted large volumes of M\&A activity since 1997. In analyzing these flows, it is helpful to distinguish between two different motives for the M\&A activity: creating opportunities for the future (strategic partnering) and resolving past problems (corporate restructuring). Most M\&A activity occurring in developed countries is in the industries under competitive pressure as a result of deregulation, technological renovation, or large $\mathrm{R} \& \mathrm{D}$ expenditures, and is thus intended for strategic repositioning. In developing countries, cross-border M\&As can immediately provide liquidity and prevent asset losses, and enhance resource allocation. In the long-term, M\&As potentially introduce new management and operation systems, thereby improving efficiency and competitiveness. 


\subsection{Trends and principal sectoral characteristics}

According to data assembled by the United Nations Conference on Trade and Development (UNCTAD), global cross-border acquisitions (in which a foreign purchaser acquired more than a 10 percent stake) reached $\$ 720$ billion in 1999 , up by 35 percent from $\$ 532$ billion in 1998 , whereas the majority cross-border M\&A value was $\$ 411$ billion. $^{3}$ Despite the rise in dollar values, developing country M\&A declined from $\$ 81$ billion (15 percent of total M\&A) in 1998 to $\$ 63$ billion (9 percent) in 1999. Cross-border M\&As in developing countries grew at an annual average rate of 81 percent during the period of 1991-1999, compared with 26 percent annual average growth of FDI flows in developing countries. These decade averages, however, mask the sharp jump in recent years, such as 132 percent from 1996 to 1997.

Within developing countries, Latin America has been the largest target region of cross-border M\&As, most of which have been through privatization programs (figure 1). Though smaller in M\&A size, East Asia has been the fastest growing target region, growing at an annual average rate of 106 percent (table 1), again with the big absolute jump occurring after the 1997 crisis. Unlike in Latin America, cross-border M\&A activity in East Asia has been largely through sales of private firms.

The recent cross-border M\&As in industrialized countries and, to a lesser extent, in developing countries are characterized by large-scale transactions (Ghemawat and Ghadar 2000 and Economist 2000). The mega deals in industrialized economies in 1999

\footnotetext{
${ }^{3}$ UNCTAD introduced a new statistics of acquisitions of a more than 10 percent stake, which is more comparable to FDI statistics. We do not have information of 1999 according to this definition, and hence no comparison is made to the rest of the statistics based on the majority acquisitions of a more than 50 percent stake.
} 
include acquisitions of AirTouch Communications of the United States by Vodafone Group PLC in the United Kingdom for $\$ 65.9$ billion and Atlantic Richfield Co. of the U.S. by BP Amoco PLC in the UK for $\$ 33.7$ billion. Mega transactions in developing countries, notably in Latin America, have been closely related to privatization projects, such as the sale of Brazil's Telebras for \$19 billion in 1998 and Argentina's petroleum company YPF SA for \$19 billion in 1999.

\subsection{What drives M\&A?}

M\&A activity create competition for corporate control, motivated by both private and regulatory incentives. Private incentives include imperfections and asymmetries in domestic product and capital markets (Kindleberger 1969, Caves 1971, Hymer 1976, and Froot and Stein 1991), competitive environment of the market, differences in tax systems (Scholes and Wolfson 1990). The imperfections and costs motivate firms to pursue mergers and acquisitions to capitalize on monopoly rents or internalize operations. Regulatory incentives include variations in corporate governance (Jensen 1986), and policy frameworks towards foreign investment. ${ }^{4}$ Management that acts in its own interest may cause financial losses to shareholders, which provides a potential for other firms to intervene. Liberalization of foreign entry and ownership will open up more opportunities for cross-border M\&A activity.

Though the distinction is not always clear-cut, M\&A activity can be broadly classified into two categories (table 2). The first type of M\&As is mainly motivated by past problems and attempts to create value through restructuring. The second type is

\footnotetext{
${ }^{4}$ A comprehensive summary of the literature is also provided in Kang (1993).
} 
forward looking, seeking to create value through creative partnerships. Negative features of M\&A arise if the first type is driven by "fire-sales" of distressed firms, and the second type of M\&As is triggered by firms seeking for market monopoly. In both cases, mismanagement may destroy shareholder value.

The upsurge of M\&As in the United States in the 1980s reflected the need to revitalize domestic firms to a new reality of increased global competition. Acquisitions by foreign firms were significant. During the 1985-1989 period, foreign acquisitions of U.S. firms amounted for over $\$ 170$ billion, 17 percent of total U.S. takeover activity (Harris and Ravenscraft 1991). Japan was one of the major investors, with a $\$ 13$ billion outlay in 1988 for acquisitions of 132 U.S. firms (Kang 1993). Motivated largely by the value of restructuring the acquired firms, these early U.S. M\&A were similar to the M\&A in post-crisis East Asia. In the U.S. M\&As of the 1980s, the firms were under competitive pressure to rationalize and raise profitability, whereas East Asian firms have been struggling to recover from severe financial distress and also improve their long-term competitiveness.

In contrast, the recent mega mergers have been largely driven by incentives for strategic partnerships to share costs of the innovation process and extend product variety. Strategic partnering through M\&As can lead to new forms of oligopolistic competition based on knowledge networks. Strategic M\&A activity can increase the operational flexibility of firms to meet new demands that are constantly generated under the continuous process of innovation (UNCTAD 1999). The sectoral examples of M\&A demonstrate the pressures for consolidation and rationalization of assets. The telecommunication and banking industries, having gone through a series of deregulatory 
measures, are dealing with a complex mix of greater competition arising from technological change and the need to supply a worldwide market. The oil and chemical industries are similarly facing the challenge of technological renovation. Firms in the pharmaceutical industry, a major target of M\&As in industrialized countries, rely heavily on R\&D, which makes strategic mergers advantageous. As these examples show, globalization heightens competition, which forces firms to rationalize internal resources and increase access to wider markets as well as to achieve economies of scale through M\&As. Meanwhile, internationalization of operation, management and financial assets can make firms more resistant to external shocks and volatility as a result of rapid globalization in developing countries.

In developing countries also, deregulation and liberalization of trade and services has opened up more opportunities for foreign investors. However, this first stage of M\&A is being driven either by privatizations of state-owned enterprises, which need significant upgrading, or by M\&As of troubled private firms.

The increased M\&A activity in the crisis-afflicted economies has been driven by exchange rate depreciations and lower domestic asset prices, which provided foreign investors with greater scope for acquiring assets. Meanwhile policy frameworks towards foreign entry have been liberalized in those economies. On the other hand, domestic firms are faced with large debt repayments in rising interest rates and thereby forced into restructuring. This has particularly been the case for those firms in the non-tradable sectors that could barely benefit from the export growth as a result of currency depreciation. For some financially troubled firms the only alternative to bankruptcy has been to sell their assets. This has let to a concern in East Asia that the current wave of 
cross-border M\&As represents "fire-sales" of domestic assets, which will result in substantial transfer of domestic wealth to foreigners, thereby involving little prospect of restructuring the troubled sectors.

\subsection{Benefits of M\&A}

We focus here on two questions. First, are cross-border M\&A different from domestic M\&As? Second, do M\&As play a special role in restructuring?

Cross-border $M \& A$ Whether cross-border M\&As bring benefits to host countries has not yet been empirically clarified. Consolidation and rationalization of resources as a result of M\&As—domestic or cross-border-can resolve over-capacity and improve efficiency. Nevertheless the immediate impact of M\&A activity may be negative as consolidation and rationalization result in reduced employment and, possibly, reduced competition.

Cross-border M\&A activity can be beneficial to a host country when it prevents potentially profitable assets from being wiped out, which is specifically applicable to M\&As involving either privatization of state-owned enterprises in transition economies or sales of financially distressed firms in developing countries. Highly indebted, lossmaking companies—-state-owned or private—often have no option but to go insolvent unless they can be sufficiently financed by external resources, most probably coming from foreign investors given domestic financial constraints. Various examples from the transition economies in Central and Eastern Europe suggest that privatization-related cross-border M\&As have played a key role in restructuring domestic firms. A study of the Czech Republic, Poland, and Hungary during the 1992-95 period indicates that 
foreign investment enterprises had a higher propensity to invest, were more exportoriented, and also were faster in restructuring, than domestic firms (Hunya 1997).

Other evidence suggests that in Hungary's banking sector, where the major privatization program has been completed, foreign investors have provided technical expertise as well as financial support, and have demonstrated greater independence from domestic political influence than domestic firms. Moreover the new entry of foreign investors into the retail market of the banking sector has increased competition, thereby promoting the development of innovative services as well as improving personnel training and marketing (World Bank 1999a).

Empirical analyses of mergers and acquisitions and corporate restructuring are, however, limited because of the lack of availability of financial information of acquired firms. Financial information of firms whose majority stake is acquired by other operating firms will be replaced by the consolidated information of the acquirers shortly after the transactions are completed. Therefore very few studies examine the long-term impact of M\&A activity on restructuring. Some analyses of U.S. firms suggest that cross-border M\&As bring larger wealth gains than domestic transactions, by comparing short-term stock returns (a few days before and after the announcement of mergers) of acquired firms. A comparative study of 1273 U.S. firms acquired during the period 1970-1987 by foreign and domestic firms shows that wealth gains for target firms observed 1-4 days after the announcement of mergers (approximated by cumulative abnormal stock returns) are significantly higher in cross-border transactions than in domestic acquisitions by around 10 percentage points (Harris and Ravenscraft 1991). Similarly, a study of Japanese merger and acquisition activity in the United States during the 1975-1988 
period concluded that the sale of a majority stake to Japanese firms leads to significantly higher target returns than the sale of a majority interest to U.S. firms (Kang 1993).

Role in restructuring Some evidence suggests that M\&As can facilitate efficient redeployment of assets of insolvent firms in the longer-term. Hotchkiss and Mooradian (1998) focused on 55 post-merger performance of insolvent firms that were acquired by other operating firms, in comparison to matching non-bankrupt transactions. The study found that post-merger cash flow returns of acquired insolvent firms improved in the first and second years by around 6 percent each, whereas post-merger cash flow returns of non-bankrupt firms showed no statistically significant improvements. They also suggested that potential sources of operating gains for the acquisitions of insolvent firms were reductions in operating expenses. ${ }^{5}$

In the long-term, however, not only can M\&As induce new investment, domestic or foreign, by the acquirers and their suppliers, but they can also introduce new managerial, production and marketing resources to target firms, thereby improving efficiency and productivity (UNCTAD 1999). Eventual integration with the corporate networks of the acquirers can further expand opportunities. Moreover, cross-border M\&As bring foreign exchange and help the developing host countries fill the gaps in their current accounts.

\footnotetext{
${ }^{5}$ There is a study of 344 cross-border and domestic M\&A transactions of U.S. firms during the 1980-1990 period, which showed that significantly high cumulative abnormal returns in cross-border acquisitions was also observed in domestic transactions (Blumberg and Owers 1996).
} 


\section{East Asian Financial Distress and Recovery}

More than two years since the onset of the East Asian crisis a strong cyclical recovery is ongoing but large parts of the corporate and financial sectors in the crisis economies remain in distress. In late 1999, non-performing loans (NPLs) in their banking systems, though lower in some countries than their historical peaks, were still at considerably high levels. In Indonesia, the Republic of Korea, Malaysia and Thailand respectively, NPLs

were 25 percent, 18 percent, 45 percent, 41 percent of gross domestic product (GDP), and an estimated 50 percent, 15 percent, 21 percent and 39 percent of total loans. ${ }^{6}$ Recovery has been strongest in Korea, which along with Malaysia, has benefited especially from the strong international demand for electronics products. And while such a recovery is likely to continue, the aftereffects of the financial shock will persist, and continued restructuring is essential both to reinforce that recovery and to reduce future vulnerabilities.

\subsection{Summary of events}

The East Asian crisis has exposed financially weak firms in the corporate sector that have operated on thin margins, and their subsequent inability to pay interest has aggravated their debt burden. Since their ability and incentives to invest are limited—and since such firms constitute a significant portion of the crisis economies - they will continue to act as a drag on investment and growth until the financial claims are resolved, and either their operations return to adequate profitability or their assets are redeployed. Meanwhile the 
distressed banking sector itself requires further recapitalization or consolidation to avoid continued systemic risks and growing fiscal liabilities for governments.

The East Asian crisis has driven many marginal firms into illiquidity, and resulted in a high level of accumulated debt and associated interest payments. Consequently, many firms that have recently emerged from the worst effects of the crisis are still in a precarious situation and are vulnerable to further shocks. Furthermore, non-performing loans by banks and non-bank financial companies have remained exceptionally high.

- Investment rates have fallen sharply since the onset of the crisis (figure 2). Relative to the average of 1992-97, the investment rates in the second quarter of 1999 were down by about 57 percent in Indonesia, 40 percent in Thailand, and by 30 percent in Korea.

- The government has borne the brunt of bank restructuring. Bank recapitalization costs are significantly large in relation to existing public debt; estimated at 48 percent, 4 percent, 8 percent, and 8 percent of GDP in Indonesia, Korea, Malaysia, and Thailand respectively (World Bank 1999b). Without the ability to collect on nonperforming loans, debt levels will show a higher than reported increase.

- In corporate restructuring in contrast, the proper role for governments is to facilitate resolution of financial claims and foster the reallocation and mobility of assets.

In the absence of effective bankruptcy regimes, governments in all the crisis countries have instituted out-of-court mechanisms to speed up financial settlements. At the same time, bankruptcy procedures, where needed, have been reformed, which may also help resolution of financial claims in the short run and may provide a sounder basis for improved corporate governance in the long run. Once financial property rights have

\footnotetext{
${ }^{6}$ These numbers include non-performing loans purchased by asset management companies.
} 
been clarified, the market system and the private sector should be in a position to undertake the required reallocations of productive assets, but governments can play an important role in permitting greater asset mobility. Reforms following the crisis also included short-term tax regime changes to facilitate asset transactions and, more importantly from a long term perspective, better accounting standards, which should contribute to improved corporate governance through better evaluation of financial assets and liabilities (table 3).

\subsection{Sectoral Distress and Recovery}

The crisis had a disproportionate impact on firms with pre-existing structural weaknesses, and this has also consequently resulted in uneven recovery. Signs of distress and recovery become apparent through the examination of various indicators. Industrial production in manufacturing has shown significant recovery in Korea and, to a lesser extent, also in Malaysia (figure 3). This faster recovery reflects in part their greater strengths in sectors such as electronics, computers, and telecommunication equipment. Korean firms have also shown resilience in the transport equipment sector (figure 4a). Similarly Thai firms in the transport equipment sector have made a strong bounce back after a sharp decline in output, whereas Malaysian firms are still on the way to returning to the pre-crisis level (figure 4b, 4c). In Korea, Malaysia and Thailand traditional manufacturing sectors such as chemical products, cement products, metals, and machinery have only shown a limited recovery, but in some cases a decline significantly predated the crisis. 
More importantly, the most distressed sectors appear to be non-tradable/services sectors where production remains below pre-crisis levels (figure 5). In particular gross domestic product in the wholesale and retail trade as well as the finance and real estate sectors show signs of severe distress, with a sharp decline and/or slow recovery (figure 6a-c). Currency depreciations, which favor traded goods, have reduced the incentive to invest in the non-tradable sectors. The share of insolvent firms is significantly higher in the non-tradable sectors than in the tradable sectors, for instance, in Malaysia about threequarters of the non-performing loans are to enterprises in the non-tradable sectors. The high level of distress reflects prevalent problems in the non-tradable sectors, which, even prior to the crisis, had been characterized by overcapacity and low productivity (Crafts 1999), reflecting local monopolies in sectors such as retail trade and distribution. Low productivity in the real estate sector also reflects excess capacity. The Japanese experience shows that deregulation of domestic trade is an important spur to competition and to increasing productivity (Alexander 1999).

The share of firms unable to pay their debts is significantly higher in the nontradable sectors than in the tradable sectors. The estimates show that, in the second quarter of 1999, distress was especially high in the non-tradable sectors of services and real estate, as could be expected from the trends in non-tradable production (table 4). For Malaysia, where the sectoral distribution of non-performing loans is available, the data shows that the problems have worsened especially for the non-tradable sectors (table 5). Non-performing loans as a share of GDP by sector rose more rapidly in the non-tradable sectors than for manufacturing overall during the period of March 1998 and September 1999. 


\section{Cross-Border M\&As in East Asian Restructuring}

As noted, cross-border mergers and acquisitions (M\&As) can be a useful—and, unlike most other initiatives, a private-sector driven—restructuring tool for host economies when distressed firms have limited alternatives for their survival. However, a concern with respect to the possibility of "fire-sales" has been prominent in the policy discussions. "Fire-sales" of domestic assets can result in substantial transfer of domestic wealth to foreigners. Nevertheless whether they do so depends on how "fire-sales" are defined (Krugman 1998). If pre-crisis asset values had been inflated by implicit guarantees that ultimately fail, and the crisis returns the values to their appropriate level, purchases by foreigners may reflect their greater liquidity or their superior management skills, but properties are sold at equilibrium prices and there is no transfer of wealth. Alternatively, if an excessive exchange rate depreciation, perhaps the result of contagion in international markets, forces domestic firms to liquidate to pay off short-term debt, foreign firms that are not liquidity-constrained can purchase these domestic firms or projects, which will generate a stream of profit above the liquidation value once the exchange rate recovers. The domestic economy will lose because of the wealth transfer, more so if foreigners are less efficient at running domestic investment projects than local firms (see Krugman 1998). Though the evidence is not clear-cut, we do not find "firesales" to be a significant phenomenon. However, neither do we find obvious evidence for the positive effects of restructuring. 


\subsection{FDI and Cross-Border M\&As}

Majority-owned cross-border M\&A sales in the crisis countries reached $\$ 7.3$ billion in 1998 , compared with $\$ 3.6$ billion in 1997 , largely due to significant increases in M\&A activity in Korea and Thailand. In 1999, the cross-border M\&A value (including both majority and minority acquisitions) in East Asia’s crisis four countries were \$20 billion, up from $\$ 17$ billion in 1998, with $\$ 12$ billion in Korea and $\$ 3$ billion in Thailand (compared to $\$ 9$ billion and $\$ 5$ billion in 1998 respectively) (figure 7). Malaysia received a high level of cross-border M\&A deals prior to the crisis, but levels did not rise after the crisis. M\&As in Indonesia, traditionally at the miniscule level, doubled in 1999 to $\$ 2.7$ billion from 1998.

Figure 8 shows the sectoral distribution of cross-border M\&As in the crisis countries during the period of 1997-1999. Indonesia had half the number of transactions in light manufacturing (mainly food products), and petro-chemicals (mainly oil refining). In Korea and Malaysia, the wholesale and retail trade sector had the largest number of transactions, 24 percent and 30 percent of their respective totals. Korea also had a large share of sales in the petro-chemicals industry. Other sectors that sold a large number of assets in Malaysia are the finance and real estate and the light manufacturing sectors (comprising the paper and pulp, textiles, and cement industries). In Thailand, the transactions have taken place mostly in the finance and real estate and the wholesale and retail trade sectors, accounting for more than 50 percent of total sales.

\subsection{Cross-Border M\&As and Financial Distress}


Though it is early to judge the impact of M\&As in East Asia, certain conclusions can be drawn. The existing literature on U.S. firms, as noted earlier, compares pre-merger cash flow performance of target firms with post-merger performance of acquirer firms. In cross-border M\&A transactions in East Asian countries, on the other hand, the size of the acquired firms is not significant relative to foreign firms to affect the performance of acquirer firms after the mergers, which means that the post-merger performance of acquired firms will not be measured by the performance of surviving entities, unlike the studies of the U.S. cases. We focus, therefore, on industry aggregates, recognizing that this reduces the confidence in the findings since those aggregates may mask individual firm performance.

Some descriptive pictures are presented in figure 9, comparing the average recovery rate in production since the crisis with the number of cross-border M\&A sales by sector. Cross-border M\&A sales tend to take place in larger numbers in the sectors showing deeper distress and slow recovery. In Thailand, 30 percent of mergers and acquisitions occurred in finance and real estate, where GDP has declined most sharply with the slowest recovery, followed by the wholesale and retail trade sector. The petrochemicals industry has also stagnated, as seen in figure 4-c, whereas foreign investors have shown considerable interest in acquiring assets among the manufacturing sectors. On the other hand, the transport equipment sector required less asset sell-offs due to its strong upturn (figure 4-c). In Malaysia, foreign investors have bought majority stakes largely in the wholesale and retail trade and the finance and real estate sectors, those that have suffered most from fallen production and sluggish recovery. The average rate of growth in production in the finance and real estate sector still remains negative. There has 
been a relatively small number of cross-border M\&A sales in the utility (electricity, gas, and water) sector which has shown the fastest recovery among the non-tradables. The ratio of the average post-crisis growth rate of production (where there has been a positive growth) to the pre-crisis rate is 0.09 for the wholesale and retail trade sector, whereas for the utility, food, and basic metal sectors, the ratios are 1.53, 2.21 and 2.31, respectively.

In comparison, Korea's picture is somewhat ambiguous partly because production has not only declined by a smaller magnitude, but also it has recovered more rapidly than the other crisis economies. Nevertheless, the wholesale and retail trade sector, with the severest fall in production in the economy, has had by far the largest number of asset sales. As also observed for Thailand, in the transport equipment sector, which shows resilience and recovery, there has been a relatively small number of asset sales. In Korea's petro-chemicals industry, 10 out of 17 cases have taken place with major chemical and allied products companies in Europe, which appears to be part of increased global oligopolistic competition in the industry since 1998. Meanwhile, overall demand growth prospects for petroleum products in the region augment the high volume of asset acquisitions by foreign investors.

Inferences on production efficiency can also be tentatively drawn from inventory trends in Korea, where such data is available (figure 10). The patterns in inventory appear to be somewhat associated with cross-border M\&A activity: The industries with low inventory level--textile, metal, and transport equipment--show the least M\&A activity, whereas machinery and petro-chemical industries have the largest numbers of M\&A among the tradable sector. 
Table 6 shows selected companies in the wholesale and retail trade and the finance and real estate sectors, whose majority stakes were sold to foreign acquirers during 19981999. The last three columns indicate return on equity (a ratio of net income to shareholder's equity) of the companies; two years, one year, and at the most recent date available, prior to the announcement of sales. The return on equity in acquired companies had sharply deteriorated prior to the transactions in all cases. Among the wholesale and retail trade sector in Thailand, the hotel industry is considered to have a stronger potential to recover through the involvement of foreign capital. Investors from Europe, the United States and Asia's newly industrialized economies have been attracted by long-term growth prospects in the industry, as well as to assets made available in the market at lower prices as the new bankruptcy law forces the highly indebted owners to sell them off.

Besides the urgent need of distressed firms for liquidity, coupled with overall policy measures to encourage cross-border M\&As, the large number of asset sales in the finance and real estate sector has been partly driven by the recent efforts of the East Asian governments to recover assets of the nationalized banking institutions. Since, through their direct takeovers and recapitalization initiatives, governments of the crisis countries have become substantial owners of the banking systems, the reprivatization of these institutions has remained a priority that will influence the long-term structure and performance of the financial sectors. So far, efforts at privatization have been partially successful, particularly in Korea and Thailand, albeit with problems partly as a result of the continued growth of non-performing loans, which new acquirers have difficulty in valuing. 
The sale of a 51 percent stake in Korea First Bank, one of the country's largest commercial banks, to a US investment fund, Newbridge Capital, was finally settled in September 1999 after nine months of negotiations. The protracted negotiations centered around the valuation of non-performing loans that had not been carved out or revealed and on the extent of continued government obligations to assume non-performing loans following the privatization. The issues were particularly serious since Korea First Bank was a principal creditor to the second largest chaebol, Daewoo where a creditor-led restructuring is ongoing as a result of the continued increase in debt. The final terms of agreement require the government to be responsible for any loans that are nonperforming over the next two years. There have been a number of smaller-scale acquisitions of Korean banks by foreign investors, including a 17 percent stake in Kookmin Bank by a Goldman Sachs-led investment fund, and a 31 percent stake in Korea Exchange Bank by Commerzbank of Germany (EIU 1999).

In Thailand, continued concerns over the scale of the non-performing loans and of asset quality, has delayed sales of the nationalized banks to foreign investors, although the slow but steady progress in the asset resolution process appears to some regaining of foreign investor confidence. ABN-Amro Bank of the Netherlands acquired a 75 percent stake in Bank of Asia, while the Development Bank of Singapore bought 51 percent of Thai Danu Bank in 1998. Nakornthon Bank (NTB) followed when Britain's Standard Chartered bought a 75 percent stake for $\$ 319$ million in September 1999 after two years of negotiations. The government is expected to reimburse Standard Chartered for any loss of interest revenue resulting from the bank's non-performing loans. Numerous minority 
acquisitions include a 15 percent stake in Thai Farmers Bank to the Government of Singapore Investment Corporation for \$258 million.

As discussed previously, some argue that the post-crisis asset acquisitions in East Asia by foreign investors are often based on "fire-sale" pricing, although evidence has been insufficient to support this argument. Limited information of cross-border M\&A transactions in Thailand suggests that prices paid by acquirers per share have been around 70 percent of book value per share (table 7). In contrast, non-performing assets in Thailand have been auctioned at values that are considerably lower than the acquisition values of local firms. The average auction price of non-performing assets in Thailand has been 25 percent of the book value (table 8 ). The case of Korea also indicates that foreign acquisitions of assets have not been "fire-sales". Korea suffered least from domestic liquidity constraint among the crisis-hit countries. Nevertheless total cross-border M\&A transactions shot up to $\$ 9$ billion in 1999, five times higher than the level in 1998. M\&A activity in Korea continued to rise by 32 percent in 1999 despite the considerable appreciation of the won by 15 percent from 1998. This suggests, therefore, that foreign acquisitions of assets have been driven by not only their greater liquidity from foreign exchange depreciation, but also new opportunities as a result of improved policy environment towards M\&As.

In summary, financial and corporate restructuring is not a short process, and clear outcomes have largely yet to materialize. East Asia's financially distressed firms have so far made major progress in the rescheduling of debt as a short-term agenda item of restructuring. Once the troubled firms stabilize their liquidity position, further steps 
would be needed towards longer-term restructuring measures-such as re-organization, changes in management, and reductions in excess capacity—which often require new investments. ${ }^{7}$ Successful firms in market economies restructure continuously in order to reposition their businesses and thus remain competitive to survive in the long term. Restructuring occurs when a firm shifts its product mix and cost structure and positions itself dynamically to remain competitive in response to changes in technology and public policies. Alongside those measures of so-called operational restructuring, the firms' assets need also to be rationalized. Reallocation of assets requires effective methods for asset pricing, which in turn requires credible bankruptcy procedures and a market for mergers and acquisitions, including liberal foreign investment rules.

\section{Policy implications}

Cross-border M\&A activity can bring most benefit to the host country when facilitated by certain policy frameworks. After a crisis, once the first step of loss allocation and transfer is complete, liberalization of foreign investment and ownership as well as tax incentives can amplify resource mobility. Introduction of institutional bankruptcy laws and accounting standards, alongside reinforcement of shareholders' rights will improve corporate governance. Meanwhile, the potential downside of M\&A activity, such as higher market concentration and immediate unemployment effects, can be avoided by removing bureaucratic barriers to competition and increasing the flexibility of labor market.

\footnotetext{
${ }^{7}$ Claessens, et. al. (1999b) indicate that concentration of ownership as well as extensive links between financial institutions and corporations are likely to delay restructuring in East Asian crisis economies.
} 
Loss allocation and transfer East Asian governments have taken several steps to achieve above agenda, as summarized in Table 3. To facilitate debt restructuring, corporate tax rates have been reduced and tax exempted on interest from non-performing assets in Indonesia and Malaysia. Korea and Thailand adopted new methods of capital valuation as well as asset depreciation towards the same goal.

Resource mobilization The second step of resource mobilization includes measures that are directly related with M\&A activity, both international and domestic, such as liberalization of foreign investment and ownership as well as tax reduction and exemption on real estate transfer. Success of mergers and acquisitions depends heavily on procedural simplicity and clarity.

Since their crises in 1997, both Korea and Thailand have introduced various measures to encourage business consolidation involving mergers and acquisitions, which have led to the rapid rise in cross-border mergers and acquisitions in these two countries. Korea has been providing tax exemption and deferral on capital gains from so-called "big deals," that is, exchange of businesses through the transfer of shares. The Korean government also released a new legislative framework in July 1999 to reduce transactionrelated taxes incurred in corporate mergers, acquisitions, and divisions. Thailand approved a set of new measures in January 1999, including provisions for tax-free mergers and noncash acquisition of assets in cases of 100 percent mergers, and for the elimination of all taxes on asset transfers from debtors to creditors. Moreover new bankruptcy procedures introduced in March 1999 allow creditors to force business restructuring on insolvent firms. As a result, firms with high liabilities have no other choice but to sell their assets as banks push them to repay their debts. 
In addition to these measures, Korea and Thailand have also taken effective steps to deregulate and liberalize their foreign investment policies since late 1997. Korea has opened several sectors to foreign investors since April 1998, including various property businesses, securities dealings, and other financing businesses. The ceiling on foreign stock investment was abolished as of May 1998, granting foreign investors the right to purchase all the shares of a domestic firm. Meanwhile, the Foreign Investment Promotion Act of November 1998 affords protection for foreign direct investment through national treatment, the reduction and exemption of certain corporate taxes, the provision of financial support for local governments to attract foreign direct investment, and the establishment of foreign investment zones. In Thailand, the Board of Investment has eased its regulations to promote foreign participation in the economy. The twenty-year old Alien Business Law was replaced in August 1998 (and has since been revised again in October 1999) to incorporate sectoral liberalization measures. Under the August 1998 provisions, foreign firms are allowed to hold up to 100 percent equity in banks and in finance companies for up to ten years, and 39 sectors have been opened up to increased foreign participation, including transportation and pharmaceuticals production. Policy liberalization includes a temporary measure introduced in November 1998 (expiring in December 1999) allowing foreign firms to own a majority stake in joint ventures that received favorable policy treatment, and authorizing them to distribute their products domestically. In the meantime, the proposed cutback of import tariffs is expected to help reduce production costs for both domestic and foreign firms dependent on imported raw materials and intermediate products. 
Unlike in Korea and Thailand where cross-border mergers have shot up, in Malaysia, cross-border mergers and acquisitions have been low compared to its own historical performance. Malaysia has, however, had high levels of domestic mergers and acquisitions. ${ }^{8}$ Malaysia's Promotion of Investment Act 1986 and other measures provide various tax incentives, including investment tax allowances in the services sector. The high level of domestic merger and acquisitions activity in Malaysia suggests that the regime is basically a friendly one. However, cross-border activity could remain low, on account of restrictions on the repatriation of earnings. More recently, Malaysia has endorsed an extensive merger program of the banking system, in which all the banking institutions have submitted their merger proposals by end-January 2000. In contrast, the Indonesian system appears not to favor mergers and acquisitions. Gains from transfers of assets in corporate reorganizations are taxable, and companies cannot transfer tax losses in a liquidation process, merger, or acquisition (Asia Law 1998). Certain exceptions apply only to banks, financial institutions, and companies going public. The sales of banking institutions have been deterred, due also to difficulties in valuation of nonperforming loans as in the other crisis countries. Overall merger and acquisition activity has remained at extremely low levels.

Corporate governance Finally, the third step of enhancing corporate governance can also be highly effective in encouraging market-driven M\&As. Some studies of ownership structures in East Asian firms suggest large family control disadvantaging shareholders (Claessens, Djankov, Fan, and Lang 1999 and Claessens, Djankov, and Lang 1999). Good corporate governance can improve distribution of control. 
Improvement of enterprise monitoring, disclosure of information, accounting practices, and equity issuance processes are essential to strengthen corporate governance frameworks. Korea and Thailand have taken steps to enhance institutional voter rights and increase the number of shareholders to exercise their rights. The amendment to the bankruptcy code in Thailand, which came into effect in March 1999, is an example of an effective measure to encourage mergers and acquisitions through market forces. In Thailand, as previously discussed, financially distressed sectors such as the hotel industry have been attracting a high level of foreign interest for its long-term growth prospects since the bankruptcy laws have been amended. The new codes allow creditors to enforce resolution of assets on debtors for repayments. Meanwhile, Korea's movement towards international accounting standards has been welcomed by foreign investors whose concerns over the acquisition of Korean assets were centered around the valuation of non-performing loans. Korea also introduced new requirements for domestic companies to increase the involvement of non-insiders on their boards On the other hand, efforts to improve corporate governance in all crisis countries. Those measures have been important to increase transparency and accountability, though further progress has yet to be made.

Competition policy and labor mobility Certain policy measures should be taken to avoid any potential downsides and induce utmost benefit of cross-border M\&As. Consolidation and rationalization through M\&As may lead to a higher degree of concentration as well as employment reduction in the host market, which particularly will apply to sectors with

\footnotetext{
${ }^{8}$ The total number of domestic mergers and acquisitions has been about 50 to 70 per quarter in Malaysia in
} 
excess capacity. To maintain the right balance between competition and cooperation has been an important concern for East Asian policy makers (Stiglitz 1996 and Mody 1999). In so doing, market-oriented measures need to be taken by reducing bureaucratic restraints to competition and monitoring market shares. Moreover, domestic firms could be provided with incentives to invest in research and development and to form strategic alliances with advanced companies, which will increase competitiveness through continuous technological renovation. Meanwhile social security systems could be improved, e.g. by tentatively extending the coverage of unemployment insurance, to support the laid-off due to M\&A activity, whereas vocational training could be provided to enhance flexibility of the labor market.

Lessons from M\&A activity in Japan The Japanese case also gives a good example where improved regulations governing mergers and acquisitions have contributed to the restructuring process. According to Alexander (1999) and UNCTAD (1999), mergers and acquisitions are occurring in numbers unprecedented for Japan, though their importance to the economy is still a small fraction of that in the United Kingdom or the United States. The value of foreign takeovers in Japan rose from US\$1.1 billion in 1997 to US $\$ 6.9$ billion in 1998 , and then shot up to US $\$ 24.2$ billion in 1999 , accounting for 32 percent of the country's total M\&A activity. Major transactions include sales of a majority stake in Yamaichi Securities to Merrill Lynch (the United States) in 1998, and in Japan Leasing to General Electric for $\$ 6.6$ billion, as well as a 37 percent stake of Nissan Motors to Renault (France) for \$5.4 billion. Similarly, domestic mergers and acquisitions 
have also risen briskly as M\&As are becoming acceptable business transactions among Japanese firms, a fundamental change from the previously held view that M\&As are predatory actions.

The rise in Japanese M\&A is partly explained by the elimination of crossshareholdings, as the returns on these equity holdings have been persistently low or negative. At the same time, many regulatory constraints on business activities are being removed, and specific measures to facilitate mergers and acquisitions are being instituted. For instance, a 1997 amendment of the Commercial Code by the Japanese Diet reduces the number of shareholder meetings required to approve mergers. The Holding Company Law of 1997 removes constraints on carving out subsidiaries for sale and allows buyers more freedom in structuring their acquisitions. The securities transaction tax formerly required when an acquisition involved share purchases was discarded in April 1999. In addition, the moves to implement international accounting principles and, in particular, consolidated reporting, are bringing more transparency to the operation of subsidiaries.

\section{Conclusion}

Foreign investors, who see opportunities in corporate distress, lower asset prices, and more liberal policies towards M\&As and FDI in general, have been attracted to the postcrisis East Asia. Cross-border M\&A activity in the crisis- countries has largely concentrated in the most troubled sectors of the crisis countries. Some non-tradable sectors as well as traditional manufacturing sectors suffer from excess capacity as a consequence of over-investment since the early 1990s, and thereby from lower capacity 
utilization and reduced production. Moreover a large number of firms carry large debt repayments due to rising interest rates, whereas other domestic companies are also financially constrained. East Asian governments have taken several steps to encourage mergers and acquisitions, whereas, albeit to varying degrees, foreign investment has been liberalized.

However, cross-border M\&A activity is still in its early phase in East Asia's financially distressed economies, and remains small, relative to the stage of development and the size of their economies. ${ }^{9}$ The recent upsurge in M\&A activity in East Asia, particularly in Korea, are largely attributed to changes in policy environment that used to work against foreign acquisitions of local assets. Liberalization of foreign entry and ownership restrictions alongside introduction of international accounting standards and shareholding systems has exponentially increased access for foreign investors to the local market and acquire assets.

The immediate role of cross-border M\&As has been to provide sufficient funds and to preserve the existing assets that would otherwise have been wiped out. In the longterm, M\&As can bring in more FDI by the acquirers and their suppliers and new resources in management and production to host countries. Eventual integration with the corporate networks of the acquirers will expand their opportunities for higher industry diversification. Though M\&A has been most prominent in distressed sectors, at this stage there is little evidence to suggest that cross-border mergers and acquisitions activity have made immediate contributions to restructuring of the troubled sectors. We should, however, highlight that the sectoral aggregates may not reflect the full effect of M\&As on 
recovery of the distressed sectors. It will require some firm-level analysis to draw more robust conclusions.

Given the gravity of problems in some sectors such as the non-tradables, the restructuring effects of cross-border M\&As may not materialize in such a short time span. The most significant role for cross-border M\&As lies in longer-term restructuring processes such as operational restructuring and reallocation of assets. Foreign participation through M\&As could also be more effective in achieving improved efficiency and competitiveness as well as better corporate governance. Under the circumstances, foreign direct investment, in the form of cross-border mergers and acquisitions, has a significant role to play in restructuring and development of financially distressed economies.

"Fire-sales" are also not evident. For the few transactions for which we can compare sale prices to book value, the receipts have been surprisingly high. Moreover, Korea has had the highest level of M\&A despite the least liquidity constraint. Also, the levels of M\&A activity have continued to remain high despite appreciation of exchange rates from their lower levels, especially but not only in Korea.

\footnotetext{
${ }^{9}$ Cross-border M\&As account for 0.6 percent of GDP in East Asia in 1998, significantly lower than 1.5 percent of GDP in Latin America.
} 


\section{Bibliography}

Alexander, Arthur. 1999. "Japan Confronts Corporate Restructuring." Background paper for Global Economic Prospects and the Developing Countries 2000, World Bank. Washington D.C.

Asia Law 1998. Cross-border M\&A: A guide to global strategic direct investment for Asian companies. Asia Law \& Practice, Ltd., Euromoney Publications.

Blumberg, Aryeh and James E. Owers. 1996. "The Convergence of Foreign Direct Investment and Restructuring: Evidence from Cross-border Divestitures." Global Finance Journal 7(1): 67-87.

Caves, Richard E. 1971. "International Corporations: The Industrial Economics of Foreign Investment.” Economica 38: 1-27.

Claessens, Stijn, Simeon Djankov, and Daniela Klingebiel. 1999a. "Bank and Corporate Restructuring in East Asia: Opportunities for Further Reform." Financial Sector Discussion Paper 3, World Bank. Washington D.C.

Claessens, Stijn, Simeon Djankov, and Daniela Klingebiel. 1999b. "How to Accelerate Corporate and Financial Sector Restructuring in East Asia." Viewpoint 200, World Bank. Washington D.C.

Claessens, Stijn, Simeon Djankov, Joseph P. H. Fan, and Larry H. P. Lang. 1999. "Expropriation of Minority Shareholders: Evidence from East Asia." Policy Research Working Paper 2088, World Bank. Washington D.C.

Claessens, Stijn, Simeon Djankov, and Larry H. P. Lang. 1999. "Who Controls East Asian Corporations?" Policy Research Working Paper 2054, World Bank. Washington D.C.

Crafts, Nicholas. 1999. "East Asian Growth Before and After the Crisis." IMF Staff Papers 46(2): 139-66.

Economist. 2000. "Merger Brief: The Digital Dilemma.” July 22.

Economist Intelligence Unit. 1999. Business Asia. September 1999.

Froot, Kenneth R. and Jeremy C. Stein, 1991. "Exchange Rates and Foreign Direct Investment: An Imperfect Capital Market Approach.” Quarterly Journal of Economics 106: 1191-1217.

Ghemawat, Pankaj and Fariborz Ghadar. 2000. "The Dubious Logic of Global Megamergers." Harvard Business Review July/August. 
Harris, Robert S. and David Ravenscraft. 1991. "The Role of Acquisitions in Foreign Direct Investment: Evidence from the U.S. Stock Market." Journal of Finance 46(3): 825-844.

Hotchkiss, Edith S. and Robert M. Mooradian. 1998. "Acquisitions as a Means of Restructuring Firms in Chapter 11." Journal of Financial Intermediation 7: 240-262.

Hunya, Gabor. 1997. Foreign Direct Investment and its Effects in the Czech Republic, Hungary, and Poland. The Vienna Institute for Comparative Economic Studies (WIIW). No. 186.

Hymer, Stephen H. 1976. The International Operations of National Firms: A Study of Direct Foreign Investment. MIT Press, Cambridge, Massachusetts.

International Monetary Fund. Various issues. International Financial Statistics. Washington D.C.

International Monetary Fund. 1998. World Economic Outlook 1998. Washington D.C.

International Monetary Fund. 1999. Financial Sector Crisis and Restructuring-Lessons From Asia. August 12, 1999.

Jensen, Michael C. 1986. “Agency Costs of Free Cash Flows, Corporate Finance, and Takeovers." American Economic Review 76: 323-329.

Kang, Jun-Koo. 1993. "The International Market for Corporate Control: Mergers and Acquisitions of U.S. Firms by Japanese Firms.” Journal of Financial Economics 34: 345371.

Kindleberger, Charles P. 1969. American Business Abroad: Six Lectures on Direct Investment. Yale University Press. New Haven, Connecticut.

Krugman, Paul R. 1998. "Fire-sale FDI." (http: / / web.mit.edu / krugman / www / FIRESALE.htm)

Mody, Ashoka. 1999. "Industrial Policy after the East Asian Crisis: From "Outward Orientation” to New Internal Capabilities?” Policy Research Working Paper 2112, World Bank. Washington D.C.

Scholes, Myron S. and Mark A. Wolfson. 1990. "The Effects of Changes in Tax Laws on Corporate Reorganization Activity." Journal Business 63: 141-164.

Stiglitz, Joseph. 1996. "Some Lessons from the East Asian Miracle." The World Bank Economic Observer 11(2): 151-177. 
Thomson Financial Securities Data. 1999-2000. SDC Platinum 2.1 - Mergers \& acquisitions database.

United Nations Conference on Trade and Development. 1998. World Investment Report 1998: Trends and Determinants. Geneva.

United Nations Conference on Trade and Development. 1999. World Investment Report 1999: Foreign Direct Investment and the Challenge of Development. Geneva.

World Bank. 1999a. Global Development Finance. World Bank, Washington D.C.

World Bank. 1999b. Global Economic Prospects and the Developing Countries. World Bank, Washington D.C.

Xie, Andy. 1999. “Korea: Another Financial Crisis?” http://www.msdw.com. 
Table 1: Cross-border mergers and acquisitions in developing countries (billions of US dollars)

\begin{tabular}{llrrrrrrrr}
\hline & & 1991 & 1992 & 1993 & 1994 & 1995 & 1996 & 1997 & 1998 \\
\hline East Asia and the Pacific & $F D I$ & 14.3 & 22.0 & 39.1 & 45.1 & 52.0 & 59.9 & 64.1 & 64.2 \\
& $M \& A$ & 0.2 & 0.3 & 1.2 & 2.1 & 1.3 & 2.0 & 6.7 & 10.1 \\
Europe and Central Asia & $F D I$ & 3.4 & 4.6 & 6.3 & 7.0 & 16.9 & 15.8 & 22.8 & 24.4 \\
& $M \& A$ & 1.1 & 3.9 & 2.4 & 2.4 & 4.3 & 2.1 & 7.8 & 1.9 \\
Latin America and the & $F D I$ & 12.8 & 15.0 & 13.7 & 28.4 & 29.8 & 43.6 & 64.7 & 69.3 \\
Caribbean & $M \& A$ & 1.0 & 6.1 & 3.8 & 3.1 & 6.0 & 11.2 & 25.6 & 31.2 \\
Middle East and North & $F D I$ & 2.8 & 3.6 & 3.8 & 3.4 & -0.2 & 3.3 & 5.9 & 5.1 \\
Africa & $M \& A$ & 0.0 & 0.3 & 0.2 & 0.4 & 0.03 & 0.2 & 1.1 & 1.2 \\
South Asia & $F D I$ & 0.4 & 0.8 & 1.1 & 1.6 & 3.0 & 3.5 & 4.9 & 3.7 \\
& $M \& A$ & 0.05 & 0.01 & 0.1 & 0.4 & 0.2 & 0.2 & 0.3 & 0.8 \\
Sub-Saharan Africa & $F D I$ & 1.6 & 1.6 & 1.9 & 3.4 & 4.2 & 4.7 & 7.7 & 4.4 \\
& $M \& A$ & 0.08 & 0.07 & 0.5 & 0.1 & 0.3 & 3.0 & 1.6 & 1.5 \\
\hline Developing Countries & $F D I$ & 35.3 & 47.5 & 66.0 & 88.9 & 105.6 & 130.8 & 170.3 & 170.9 \\
Total & $M \& A$ & 2.4 & 10.8 & 8.2 & 8.5 & 12.1 & 18.6 & 43.2 & 46.8 \\
*Involves acquisitions of a more than 50 percent equity. & & & & & & \\
Source: World Bank GDF 2000 and UNCTAD WIR 2000 & & & & & &
\end{tabular}

Table 2: Why M\&A occur?

\begin{tabular}{l|l|l} 
& PAST & FUTURE \\
\hline POSITIVE & $\begin{array}{l}\text { Overcome capital } \\
\text { market } \\
\text { imperfections }\end{array}$ & $\begin{array}{l}\text { Build value through } \\
\text { strategic partnering }\end{array}$ \\
\hline NEGATIVE & Fire-sale/monopoly & Monopoly
\end{tabular}


Table 3: Illustrative post-crisis policy reforms in crisis countries

\begin{tabular}{|c|c|c|c|}
\hline & Loss allocation and transfer & Resource mobility & Corporate governance \\
\hline Indonesia & $\begin{array}{l}\text { Tax exemptions for loan-loss reserves held } \\
\text { by banks (March 1998) }\end{array}$ & $\begin{array}{l}\text { Relaxation of foreign ownership restrictions } \\
\text { (September 1997) } \\
\text { Tax exemptions of up to } 8 \text { years for new } \\
\text { investments in } 22 \text { industries (January 1999) }\end{array}$ & $\begin{array}{l}\text { Presence of a corporate secretary to improve } \\
\text { disclosure } \\
\text { Bankruptcy Law updated (August 1998) } \\
\text { Code of best practice for corporate } \\
\text { governance (in progress) }\end{array}$ \\
\hline Korea & $\begin{array}{l}\text { Revaluation and adjustment of capital and } \\
\text { foreign exchange losses (August 1999) }\end{array}$ & $\begin{array}{l}\text { Introduction of Foreign Investment } \\
\text { Promotion Act (November 1998) }\end{array}$ & $\begin{array}{l}\text { Restrictions on cross-debt guarantees (April } \\
1998 \text { ) } \\
\text { Enhancing institutional voter rights (June } \\
\text { 1998) } \\
\text { Introduction of international accounting } \\
\text { standards (August 1999) } \\
\text { Lowering the minimum equity holding } \\
\text { requirement to exercise shareholder's rights } \\
\text { (1999) }\end{array}$ \\
\hline Malaysia & $\begin{array}{l}\text { Reduction of corporate tax rate from } 30 \\
\text { percent to } 28 \text { percent (October 1997) } \\
\text { Tax exemption on interest from non- } \\
\text { performing loans (Effective for } 1999 \text { and } \\
2000 \text { ) }\end{array}$ & $\begin{array}{l}\text { Reduction of real property gains tax rate } \\
\text { from } 30 \text { percent to } 5 \text { percent for } \\
\text { nonresidents on the sale of a property held } \\
\text { for a minimum of five years (October 1997) } \\
\text { Exemption of real property gains tax on } \\
\text { mergers of financial institutions (October } \\
1998 \text { ) }\end{array}$ & $\begin{array}{l}\text { Creation of High-Level Finance Committee } \\
\text { on Corporate Governance } \\
\text { Code on takeovers and mergers with stricter } \\
\text { disclosure standards (January 1999) }\end{array}$ \\
\hline Thailand & $\begin{array}{l}\text { Elimination/deferral of income tax and taxes } \\
\text { on asset transfer and unpaid interest } \\
\text { (January 1999) } \\
\text { Introduction of new asset depreciation } \\
\text { method (March 1999) }\end{array}$ & $\begin{array}{l}\text { Alien Business Law (August 1998, revised } \\
\text { in October 1999) } \\
\text { Tax-free mergers and acquisitions in cases } \\
\text { of } 100 \text { percent mergers (January 1999) } \\
\text { Introduction of Equity Fund, Thailand } \\
\text { Recovery Fund for large- and medium-scale } \\
\text { companies, and Venture Capital Fund for } \\
\text { small and medium-size enterprises (March } \\
\text { 1999) } \\
\text { Reduction of real estate transfer fee from } 2 \\
\text { to 0.01 percent of the appraised value } \\
\text { (March 1999) }\end{array}$ & $\begin{array}{l}\text { Financial statements of public companies } \\
\text { and financial institutions to be in accord } \\
\text { with international best practices (1999) } \\
\text { Requirement of board audit committees } \\
\text { (1999) } \\
\text { Bankruptcy and foreclosure laws amended } \\
\text { (March 1999) }\end{array}$ \\
\hline
\end{tabular}


Table 4: Financial distress, $19992^{\text {nd }}$ Quarter (percentage of firms unable to meet current debt repayments)

$1999(\mathrm{Q} 2)$

\begin{tabular}{lcccc}
\hline & All & Manufacturing & Services & Real estate \\
\cline { 2 - 5 } Indonesia & 63.8 & 41.8 & 66.8 & 86.9 \\
Korea & 26.7 & 19.6 & 28.1 & 43.9 \\
Malaysia* & 26.3 & 39.3 & 33.3 & 52.8 \\
Thailand & 28.3 & 21.8 & 29.4 & 46.9
\end{tabular}

*For Malaysia, firms in agriculture and utilities bring down the average for all firms in 1999.

Source: Claessens, Djankov, and Klingebiel (1999a)

Table 5: Non-performing loans as share of GDP in Malaysia by sector (percent)

Mar-98 Dec-98 Sep-99 Change,

Agriculture, forestry and fishing

Mining

Manufacturing

Utility

Wholesale and retail trade

Construction

Transportation and communications

Financial services

Source: Bank Negara
3/98-9/99

\begin{tabular}{rrrr}
6.4 & 11.7 & 15.0 & 58.3 \\
1.9 & 9.0 & 6.6 & 32.5 \\
24.3 & 59.1 & 56.8 & 32.7 \\
7.3 & 13.1 & 21.2 & 63.2 \\
21.8 & 46.0 & 57.2 & 58.1 \\
131.8 & 328.1 & 342.2 & 47.1 \\
23.4 & 63.3 & 52.5 & 23.5 \\
50.5 & 136.7 & 210.5 & 124.2 \\
\hline
\end{tabular}

Table 6: Return on equity of acquired companies

\begin{tabular}{|c|c|c|c|c|c|c|}
\hline \multirow[b]{2}{*}{ Company } & & \multirow[b]{2}{*}{ Sector } & \multirow{2}{*}{$\begin{array}{l}\text { Sale } \\
\text { value } \\
\text { (\$mil) }\end{array}$} & \multicolumn{3}{|c|}{ Return on equity } \\
\hline & & & & 2 years & 1 year & $\begin{array}{l}\text { Last } \\
\text { avail }\end{array}$ \\
\hline Korea First Bank & Korea & Finar & 415.0 & -1.8 & -162.0 & -1587.6 \\
\hline Shangri-La Hotels & Malaysia & Whol & 94.6 & 7.1 & 3.5 & \\
\hline Bank of Asia & Thailand & nd real estate & 181.5 & 15.9 & -4.6 & -78.8 \\
\hline Nakornthon Bank & Thailand & nd real estate & 319.3 & -4.0 & -341.9 & \\
\hline UOB Radanasin Bank & Thailand & Finance and real estate & 382.5 & -29.0 & -283.0 & \\
\hline Shangri-La Hotel & Thai & Wholes & 34.7 & 0.5 & -13.9 & \\
\hline Golden Land Ppty Dvlp & Thailand & Finance and real estate & 76.3 & -1.6 & -62.0 & \\
\hline
\end{tabular}


Table 7: Transaction value of selected cross-border M\&A activity in Thailand

\begin{tabular}{lllrc}
\hline Effective Date & Company & Industry & $\begin{array}{l}\text { Book } \\
\text { value per value as share } \\
\text { share } \\
\text { of book value } \\
\text { (US\$) }\end{array}$ & $\begin{array}{l}\text { Transaction } \\
(\%)\end{array}$ \\
\hline March 29, 1998 & Carpets International & Textile Products & 1.3 & 70.0 \\
September 24, 1999 & Shangri-La Hotel & Wholesale and retail trade & 0.9 & 72.2 \\
February 3, 2000 & United Motor Works & Transport Equipment & 3.7 & 72.7 \\
\hline Source:
\end{tabular}

Source: Thomson Financial Securities Data

Table 8: Auction results of non-performing assets (as of end-1999)

FINANCIAL SECTOR RESTRUCTURING AUTHORITY, THAILAND*

\begin{tabular}{|c|c|c|c|}
\hline Bid date & Items & Book value (baht) & $\begin{array}{l}\text { Auction value as \% } \\
\text { of book value }\end{array}$ \\
\hline June 25,1998 & $\begin{array}{l}\text { Auto hire purchase } \\
\text { contracts }\end{array}$ & 52 billion & $48 \%$ \\
\hline August 13, 1998 & $\begin{array}{l}\text { Residential } \\
\text { mortgage loans }\end{array}$ & 24.6 billion & $47 \%$ \\
\hline December 15, 1998 & Business loans & 155.7 billion & $25 \%$ \\
\hline March 19, 1999 & Business loans & 221.5 billion & $18 \%$ \\
\hline July 6, 1999 & Construction loans & 1.3 billion & $8 \%$ \\
\hline August 11, 1999 & Business loans & 129.0 billion & $24 \%$ \\
\hline November 10, 1999 & Business loans & 17.8 billion & $30 \%$ \\
\hline
\end{tabular}

* Excludes sales of non-core assets.

Source: Financial Sector Restructuring Authority

KOREA ASSET MANAGEMENT CORPORATION

\begin{tabular}{|c|c|c|c|}
\hline Bid date & Items & Book value (won) & $\begin{array}{l}\text { Auction value as \% } \\
\text { of book value }\end{array}$ \\
\hline September 1, 1998 & Business loans & 207.5 billion & $12 \%$ \\
\hline October 30, 1998 & Real estate assets & 6.0 billion & - \\
\hline December 9, 1998 & $\begin{array}{l}\text { Loans secured by } \\
\text { real estate assets }\end{array}$ & 564.6 billion & $36 \%$ \\
\hline May 27, 1999 & Business loans & 772.4 billion & $17 \%$ \\
\hline June 22, 1999 & $\begin{array}{l}\text { Loans secured by } \\
\text { real estate assets }\end{array}$ & 1.04 trillion & $51 \%$ \\
\hline November 11, 1999 & Business loans & 811.1 billion & $21 \%$ \\
\hline December 8, 1999 & $\begin{array}{l}\text { Loans secured by } \\
\text { real estate assets }\end{array}$ & 1.02 trillion & $62 \%$ \\
\hline \multicolumn{4}{|c|}{ Source: Korea Asset Management Corporation } \\
\hline \multicolumn{4}{|l|}{ DANAHARTA } \\
\hline Bid date & Items & Book value (US\$) & $\begin{array}{l}\text { Auction value as \% } \\
\text { of book value }\end{array}$ \\
\hline July 1, 1999 & Foreign loans & 94.95 million & $55 \%$ \\
\hline
\end{tabular}

Source: Danaharta 
Figure 1: World cross-border mergers and acquisitions, 1991-1999*

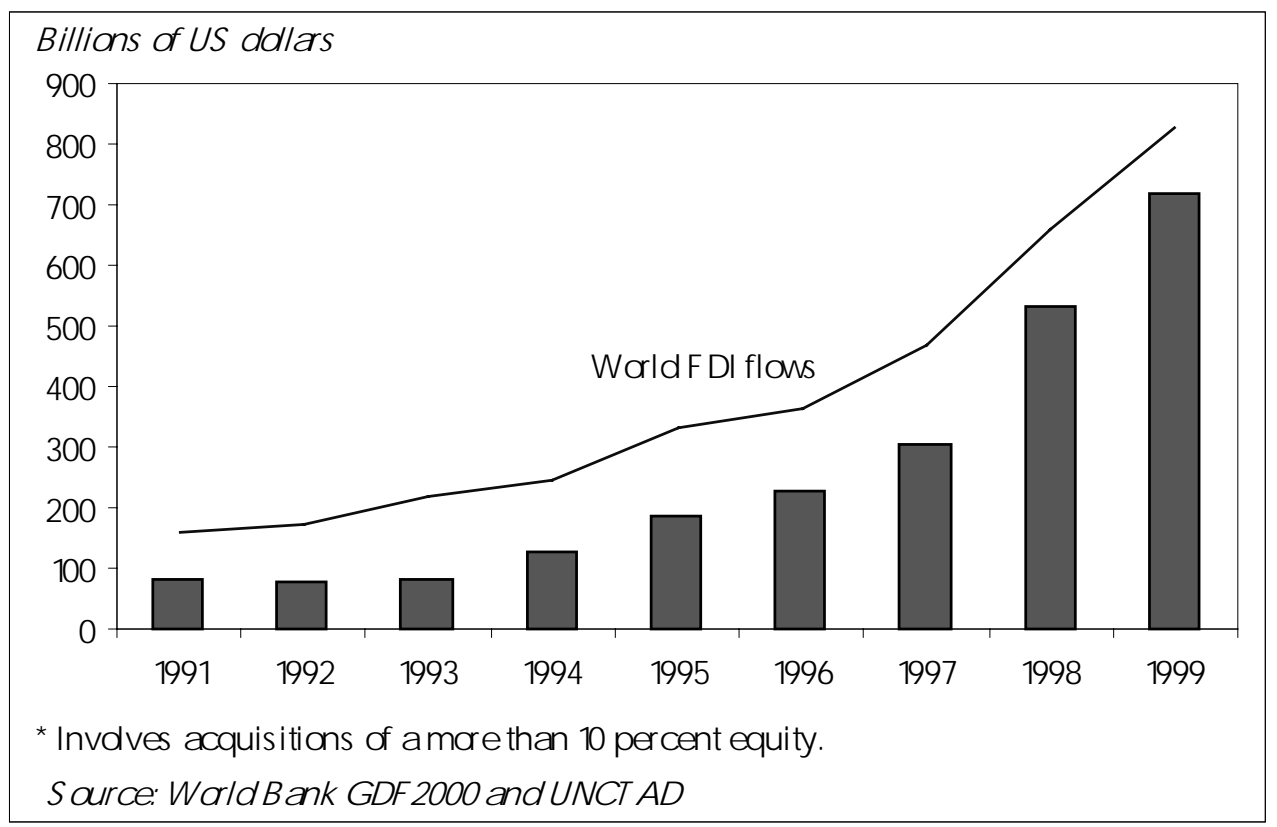

Figure 2: Total investment in East Asia (percent)

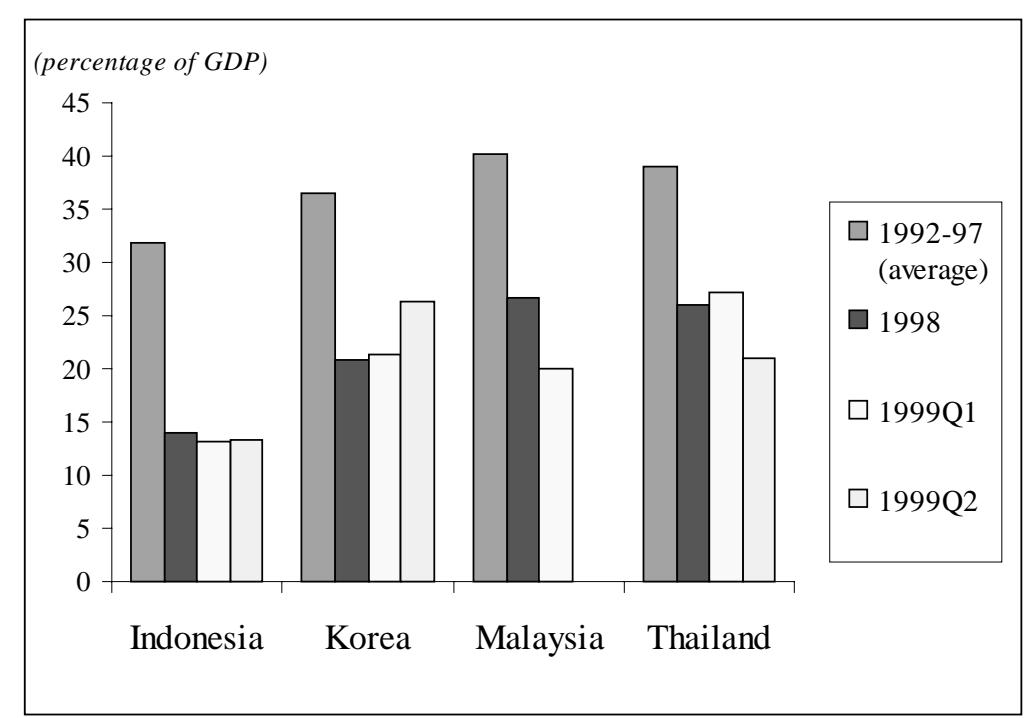

Source: IFS, IMF 
Figure 3: Industrial production before and after the crisis (index $=100$ at the start of the crisis)

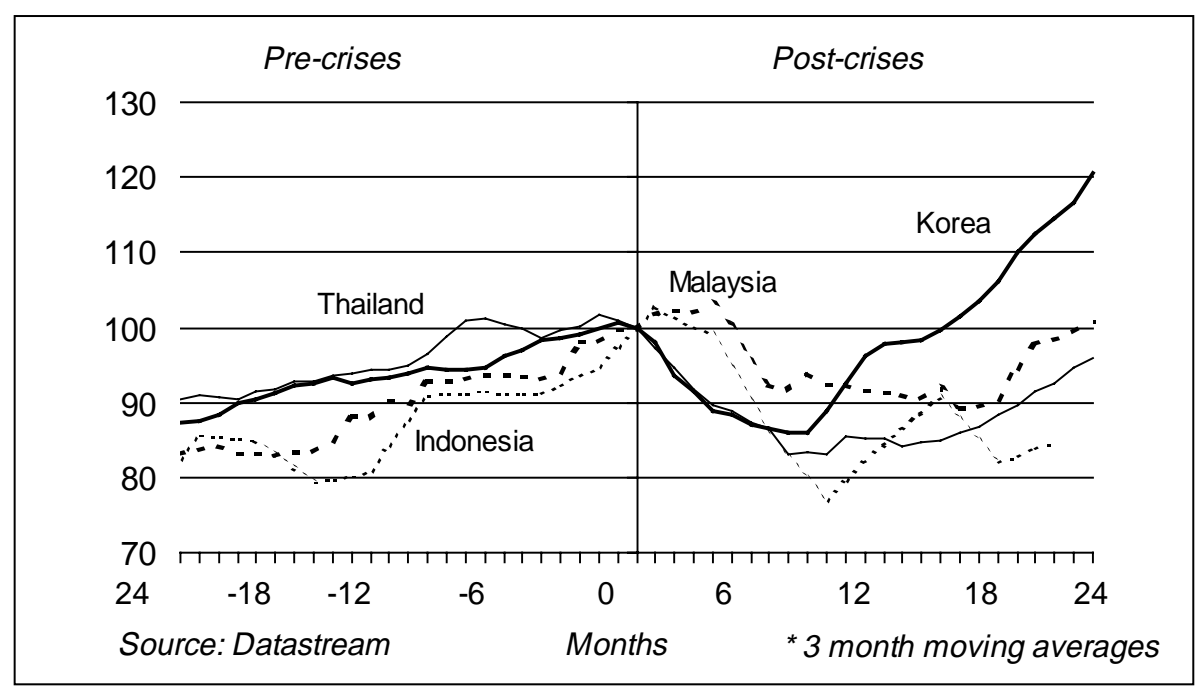

Figure 4: Production index before and after the crisis by industry (index $=100$ at the start of the crisis)

\section{a. Korea}

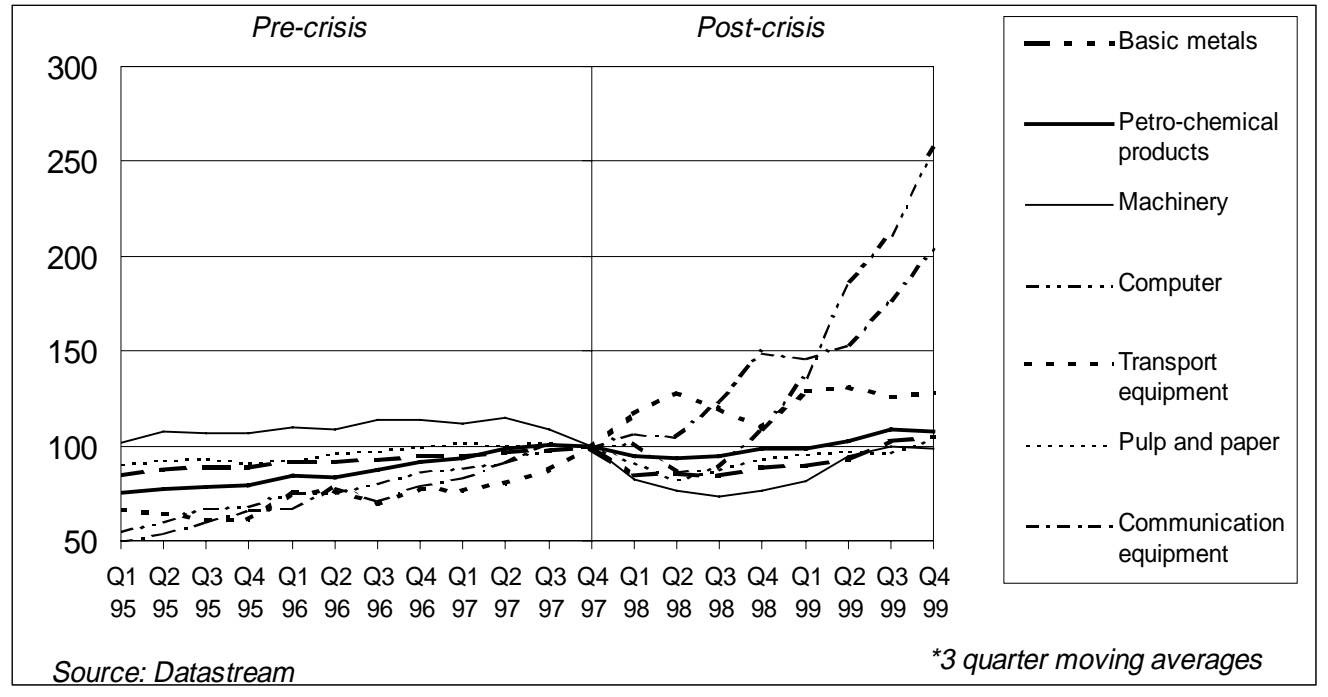




\section{b. Malaysia}

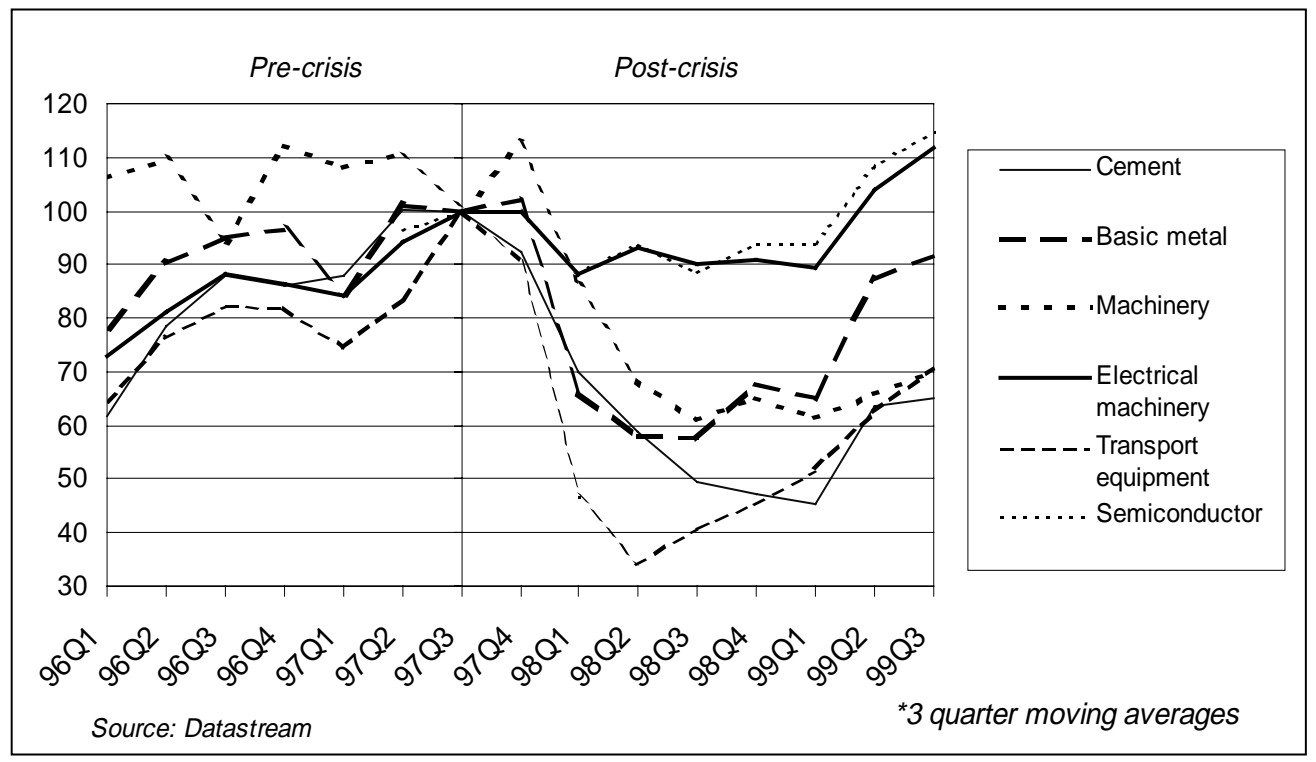

\section{c. Thailand}

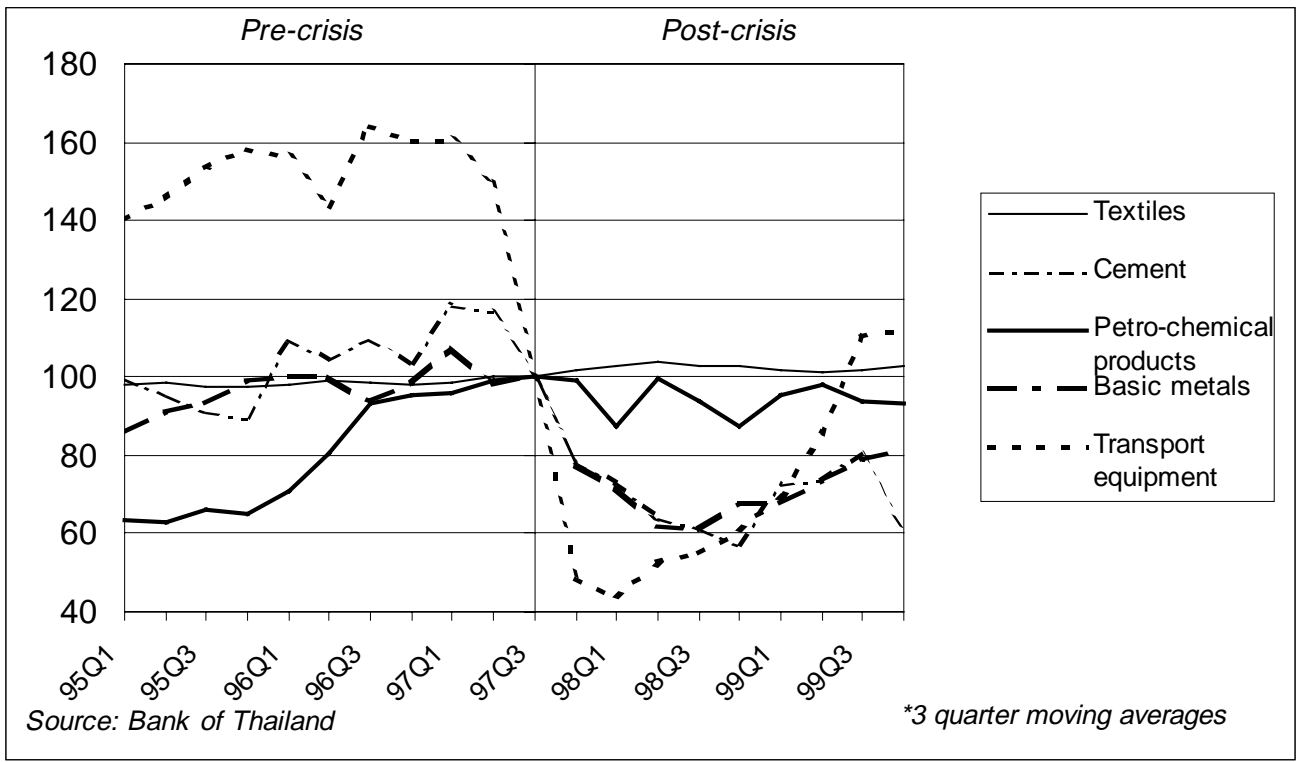


Figure 5: Non-tradable production before and after the crisis (index $=100$ at the start of crisis)

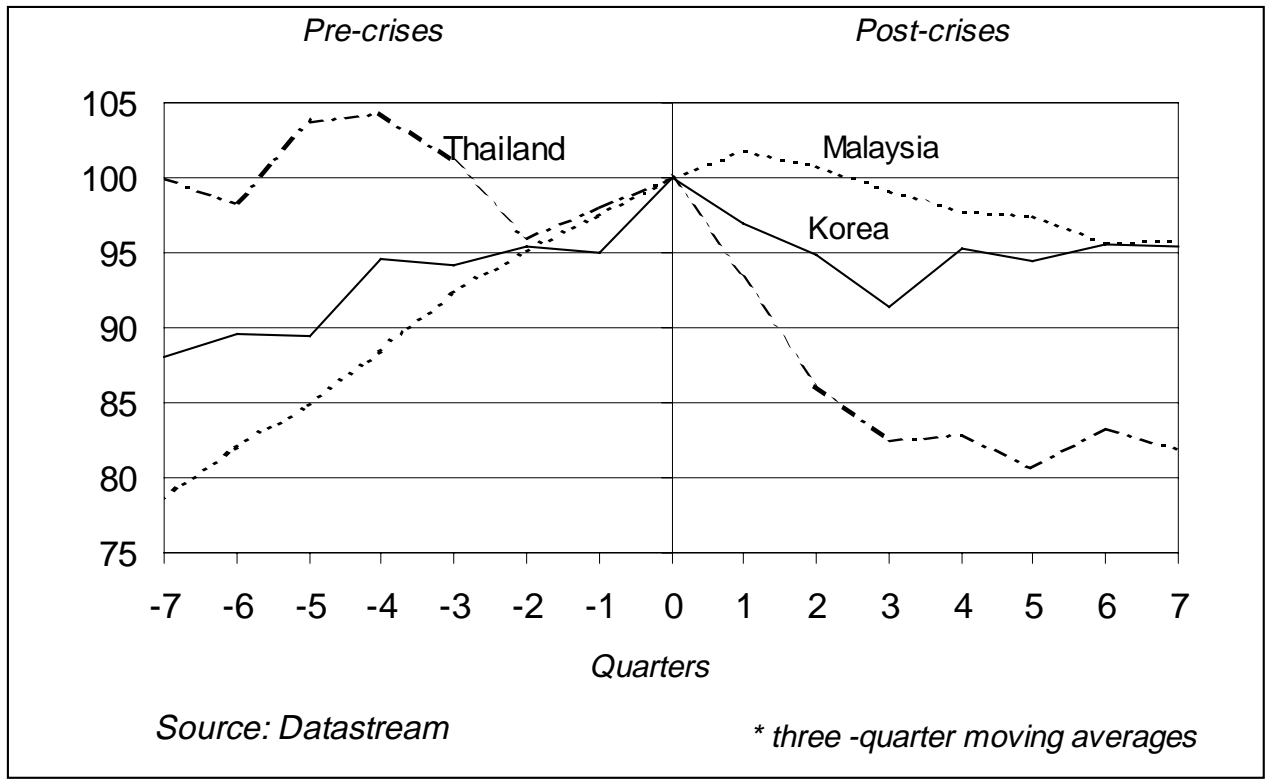

Figure 5: Non-tradable production before and after the crisis by industry (index $=100$ at the start of crisis)

a. Korea

Pre-crisis




\section{b. Malaysia}

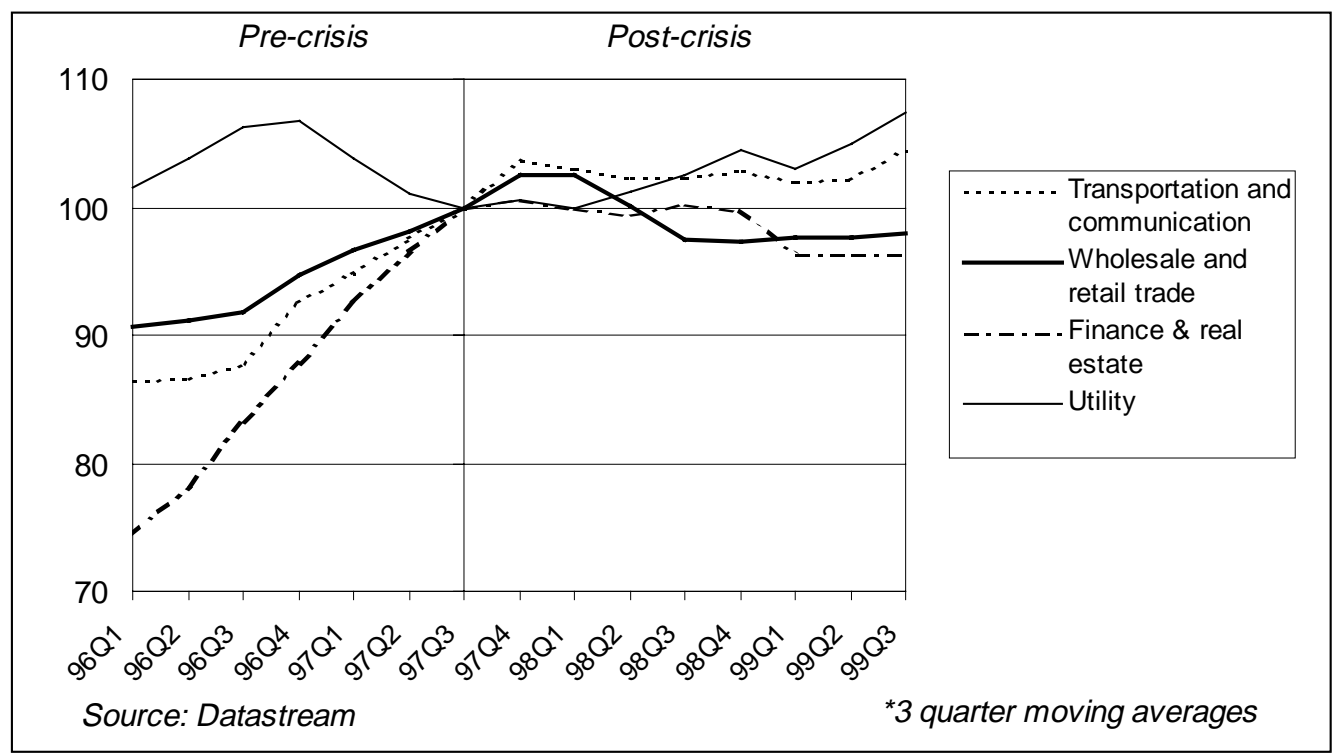

\section{c. Thailand}

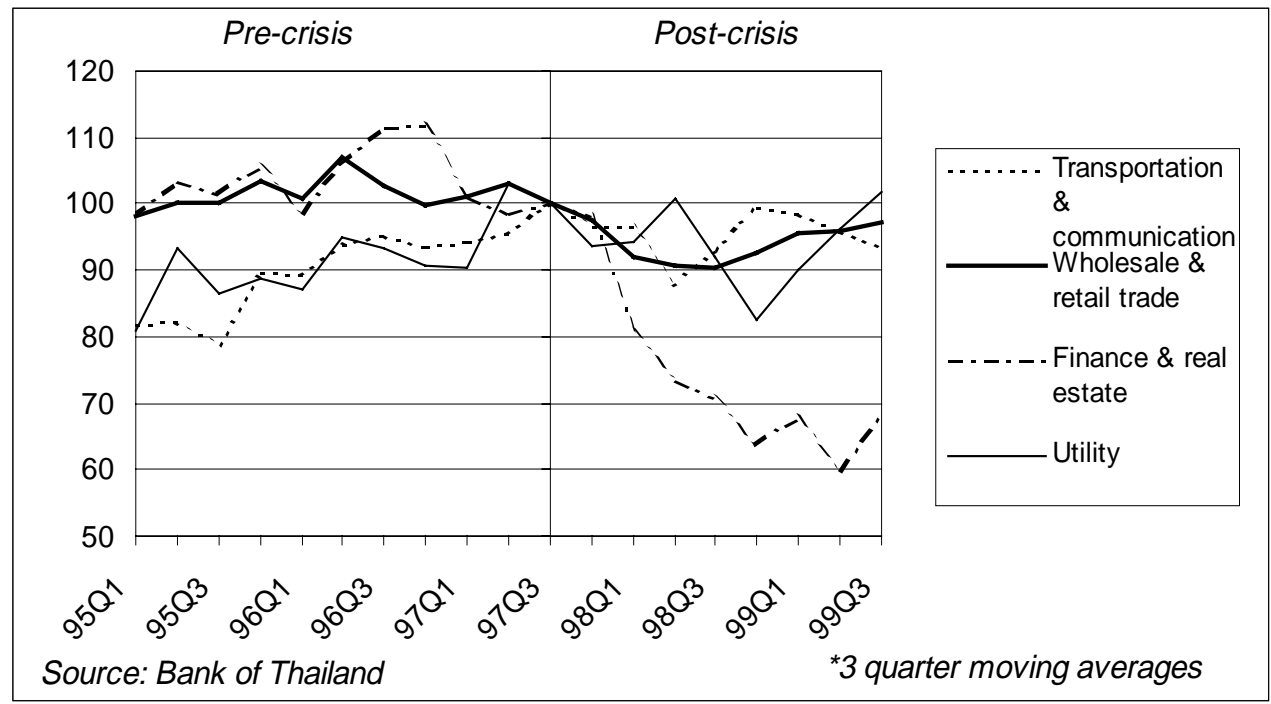


Figure 7: Cross-border mergers and acquisitions in crisis countries, 1997-1999*

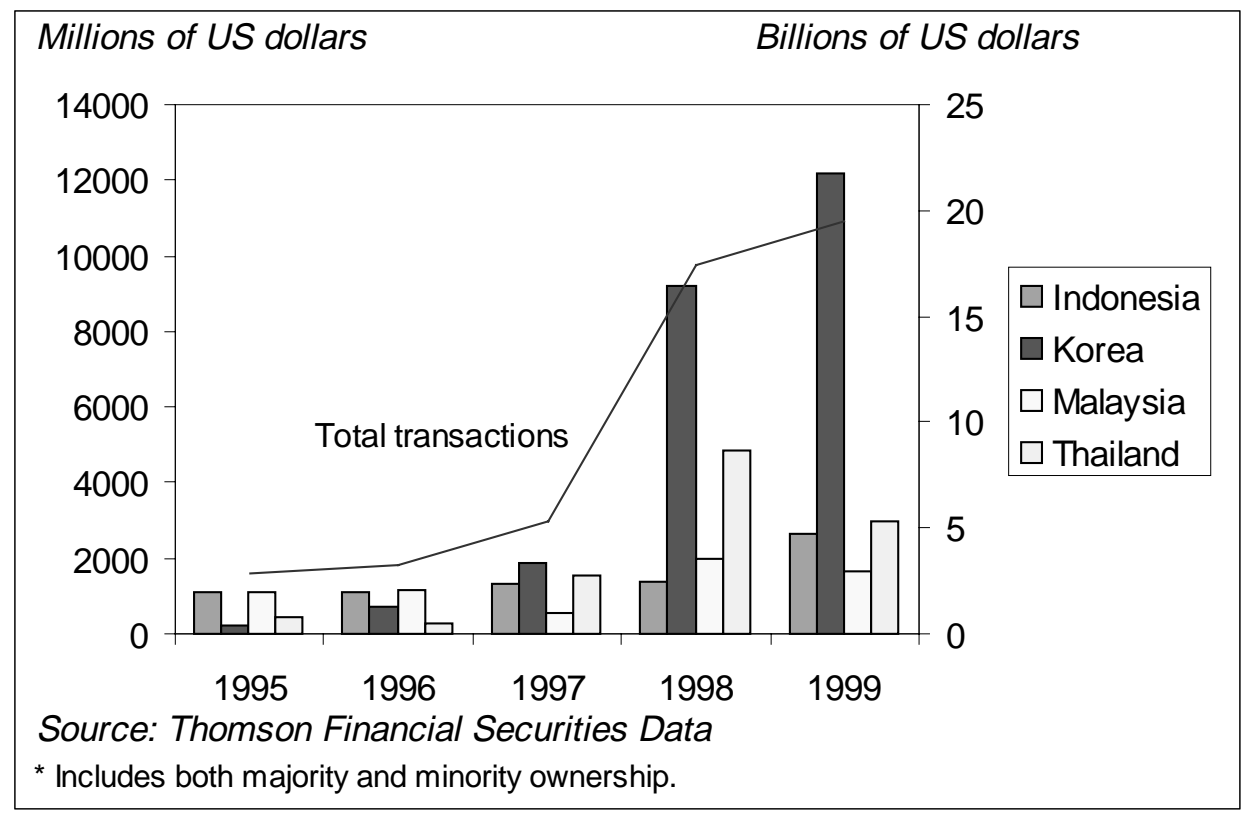

Figure 8: Cross-border mergers and acquisitions in crisis countries by sector 1997-1999 (number)

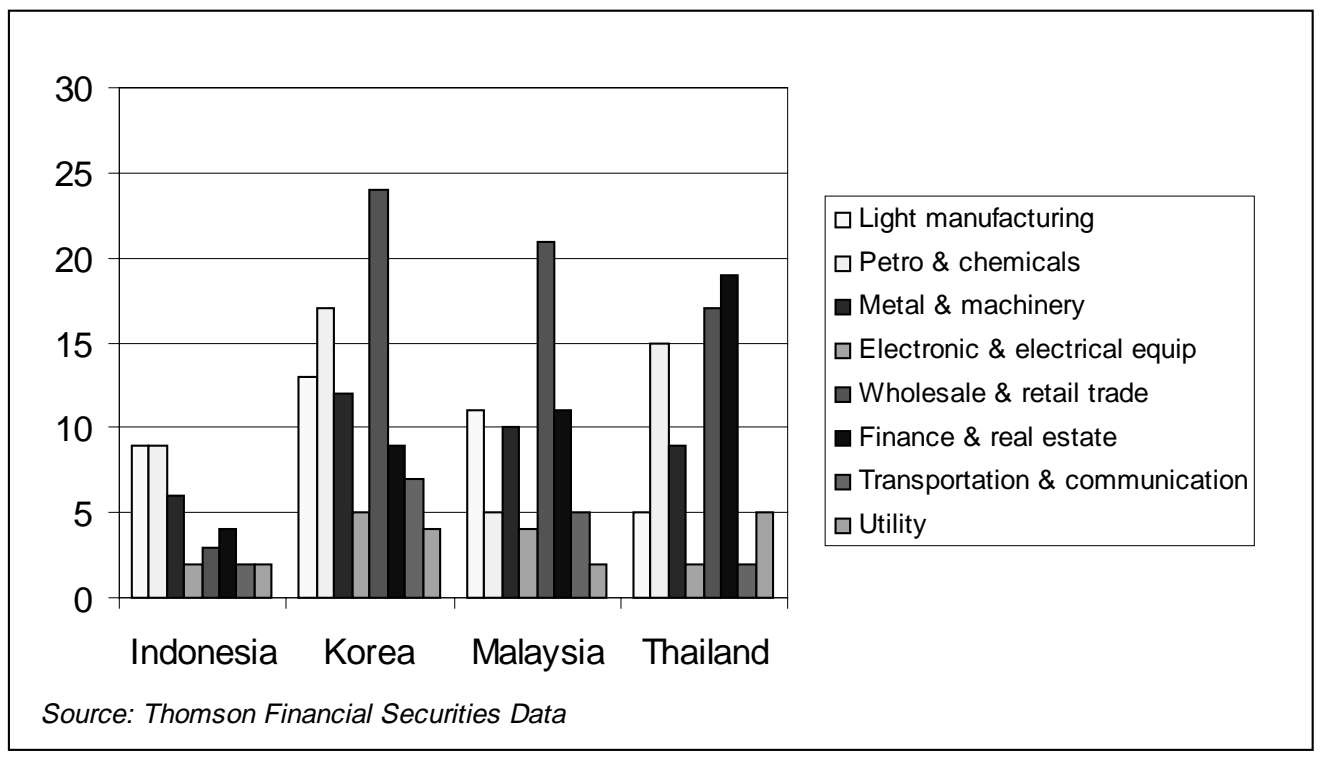




\section{Figure 9: Cross-border mergers and acquisitions and recovery in production by sector, 1997-1999 (number)}

a. Korea

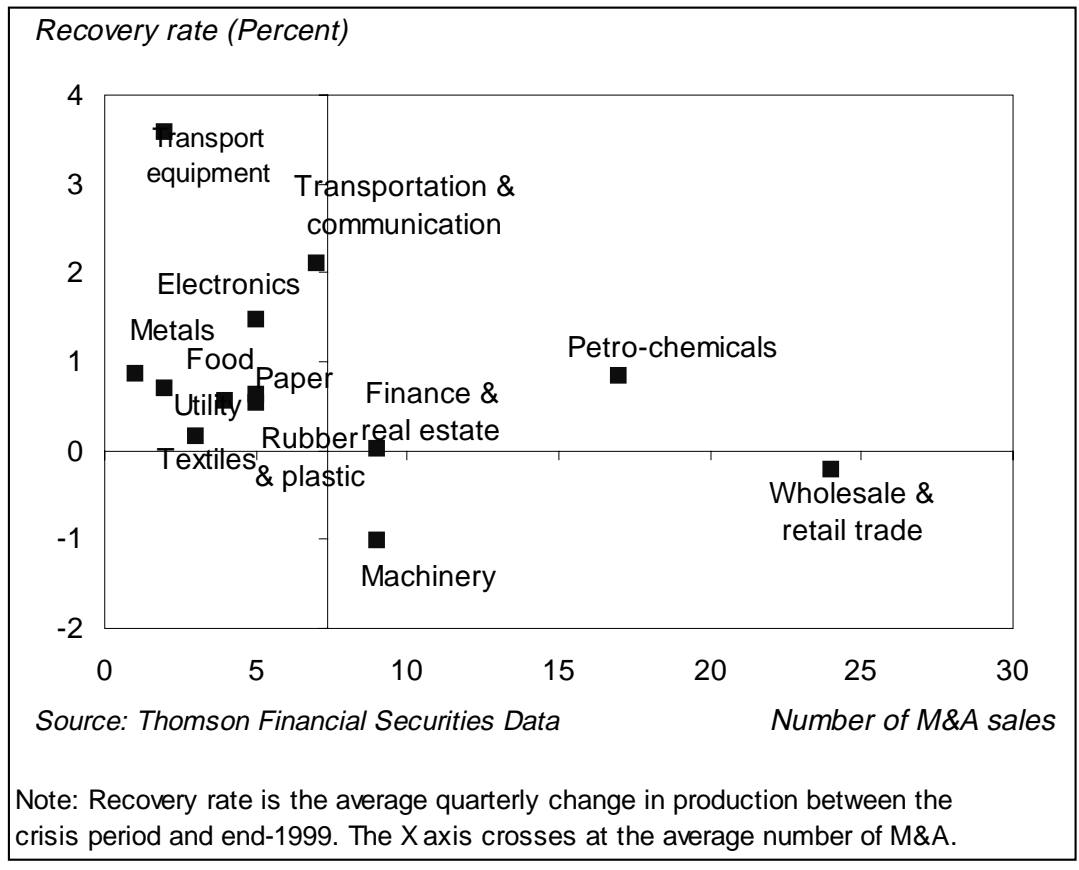

\section{b. Malaysia}

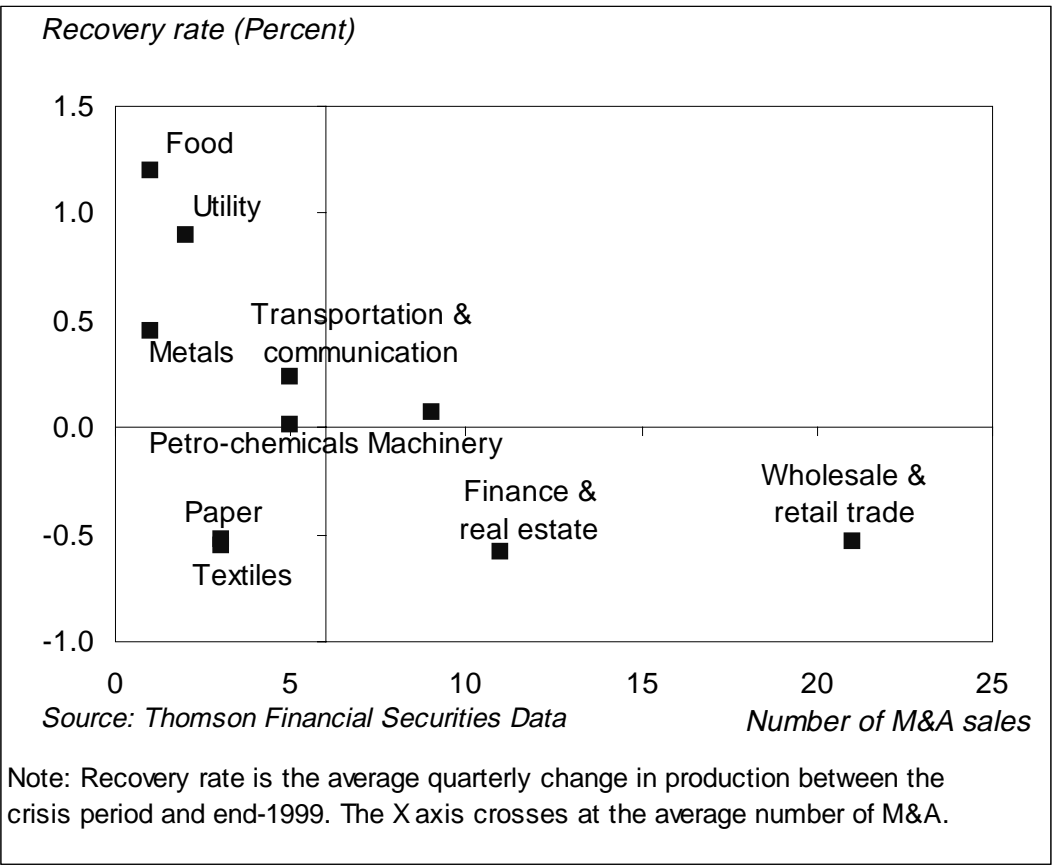




\section{c. Thailand}

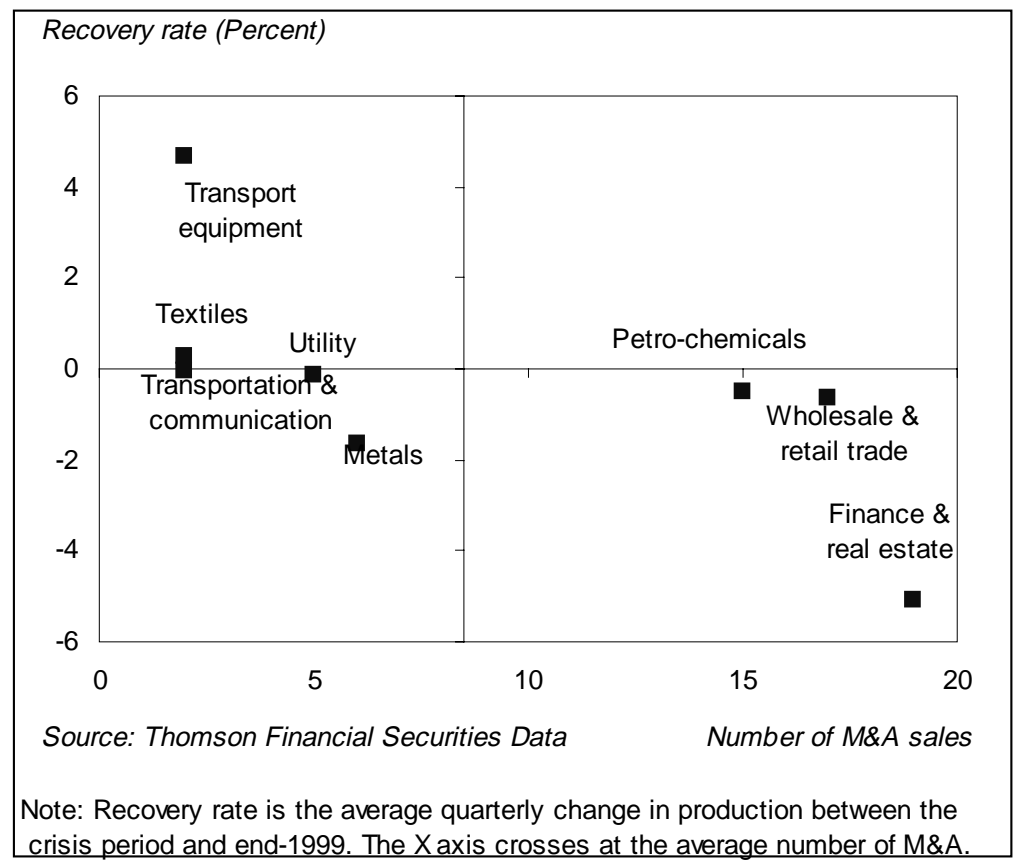

\section{Figure 10: Inventory index by industry in Korea (three-month moving average)}

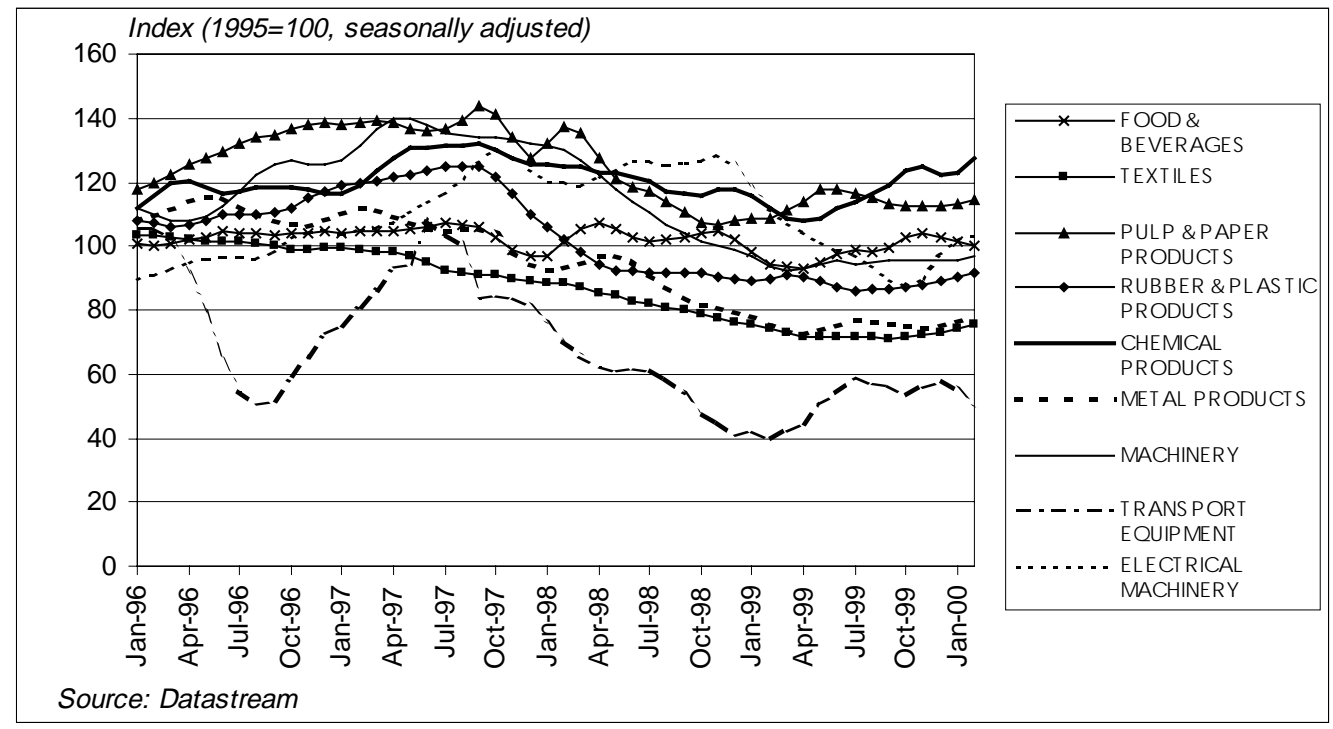

